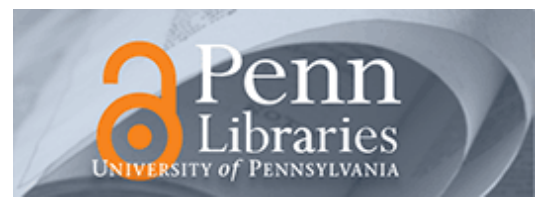

University of Pennsylvania

ScholarlyCommons

Accounting Papers

Wharton Faculty Research

$9-2009$

\title{
Bringing It Home: A Study of the Incentives Surrounding the Repatriation of Foreign Earnings Under the American Jobs Creation Act of 2004
}

Jennifer L. Blouin

University of Pennsylvania

Linda Krull

Follow this and additional works at: https://repository.upenn.edu/accounting_papers

Part of the Accounting Commons

\section{Recommended Citation}

Blouin, J. L., \& Krull, L. (2009). Bringing It Home: A Study of the Incentives Surrounding the Repatriation of Foreign Earnings Under the American Jobs Creation Act of 2004. Journal of Accounting Research, 47 (4), 1027-1059. http://dx.doi.org/10.1111/j.1475-679X.2009.00342.x

This paper is posted at ScholarlyCommons. https://repository.upenn.edu/accounting_papers/53

For more information, please contact repository@pobox.upenn.edu. 


\title{
Bringing It Home: A Study of the Incentives Surrounding the Repatriation of Foreign Earnings Under the American Jobs Creation Act of 2004
}

\author{
Abstract \\ The American Jobs Creation Act of 2004 (the Act) creates a temporary tax holiday that effectively \\ reduces the U.S. tax rate on repatriations from foreign subsidiaries from $35 \%$ to $5.25 \%$. Firms receive the \\ reduced tax rate by electing to take an 85\% dividends received deduction on repatriations in 2004 or 2005 . \\ This paper investigates the characteristics of firms that repatriate under the Act and how they use the \\ repatriated funds. We find that firms that repatriate under the Act have lower investment opportunities \\ and higher free cash flows than nonrepatriating firms. Further, we find that repatriating firms increase \\ share repurchases during 2005 by approximately $\$ 60$ billion more than nonrepatriating firms, an amount \\ that cannot be explained by differences in earnings between the two groups of firms. This increase \\ represents about $20 \%$ of the $\$ 291.6$ billion repatriated by our sample firms under the Act. \\ Disciplines \\ Accounting
}


Bringing it home: A study of the incentives surrounding the repatriation of foreign earnings under the American Jobs Creation Act of 2004

\author{
Jennifer Blouin \\ The Wharton School \\ Linda Krull \\ University of Oregon
}

July 2008

\begin{abstract}
The American Jobs Creation Act of 2004 (the Act) creates a temporary tax holiday that effectively reduces the U.S. tax rate on repatriations from foreign subsidiaries from 35 percent to 5.25 percent. Firms receive the reduced tax rate by electing to take an 85 percent dividends received deduction on repatriations in 2004 or 2005. This paper investigates the characteristics of firms that repatriate under the Act and how they use the repatriated funds. We find that firms that repatriate under the Act have lower investment opportunities and higher free cash flows than non-repatriating firms. Further, we find that repatriating firms increase share repurchases during 2005 by $\$ 55.80$ to $\$ 60.85$ billion more than non-repatriating firms. This increase represents 19.14 to 20.87 percent of the $\$ 291.6$ billion repatriated under the Act. This paper provides useful information to policy makers about the effect of a temporary tax holiday on firms' investment behavior.
\end{abstract}

Key Words: $\quad$ Multinational Firms, Foreign direct investment, Corporate Taxation, Payout policy, Repurchases

We thank Gustavo Grullon, Robert Holthausen, Ken Klassen, Art Kraft, Lil Mills, Ed Outslay, Scott Richardson, Yong Yu and workshop participants at Rice, Michigan State, Iowa, Texas, Rochester, Oregon, Georgia, Houston, the National Tax Association's $99^{\text {th }}$ Annual Conference on Taxation, the University of Utah Winter Accounting Research Conference, the 2006 University of North Carolina Tax Symposium, and the NYU Summer Camp for helpful comments and suggestions. We also thank Jim Feeney, Taylor Green, Stefan Kullberg and George Lin for diligent research assistance. 


\section{Introduction}

In recent years, U.S. multinational corporations’ profits surged as growth in global markets outpaced domestic growth. ${ }^{1}$ This international expansion led to record foreign profits for U.S. firms, which remain invested overseas unless repatriated to the United States. To encourage firms to invest these profits in the U.S., the American Jobs Creation Act of 2004 (the Act) temporarily decreases the tax burden on repatriations of foreign earnings by effectively reducing the maximum tax rate on overseas profits from 35 percent to 5.25 percent. Firms receive the reduced tax rate by electing to take an 85 percent dividends received deduction on repatriations of foreign earnings in either 2004 or 2005.

Because the intent of the legislation is to increase domestic investment, firms must have a plan to use funds remitted during the tax holiday for such purposes as capital expenditures, research and development, debt repayment, and certain merger and acquisition activity. Subsequent guidance issued by the Internal Revenue Service (IRS) specifically disallows using the funds for dividends, share repurchases, and executive compensation. Initial estimates indicate that firms could repatriate up to \$426 billion under the Act (Albring, Dzuranin, and Mills 2005). Although this estimate suggests that the Act will move large amounts of cash into U.S. investments, anecdotal evidence suggests that firms are using the repatriated funds to repurchase shares, one of the purposes specifically disallowed by the IRS. ${ }^{2}$

We study the characteristics of firms that repatriate under the Act and how they use those funds. Existing theory regarding repatriation of foreign earnings finds that taxes on unremitted

\footnotetext{
1 “U.S. Multinationals Reap Overseas Bounty”, Wall Street Journal, April 4, 2005, A2.

2 See for example, "Buybacks Soar; Firms Deny a Link to Repatriated Profit-Tax-Break”, Wall Street Journal, October 24, 2005, A2. As another example, the following quote is from "Postcards From a Tax Holiday", The New York Times, November 12, 2005: "Hewlett-Packard has announced a repatriation of \$14.5 billion, layoffs of 14,500 workers and stock buybacks of more than \$4 billion for the first half of 2005, about three times the size of its buybacks in the period a year earlier.”
} 
foreign earnings do not affect repatriations when tax rates and after-local-tax returns are constant. Under these assumptions, firms will repatriate when the after-tax return abroad is low relative to the after-tax return in the United States (Hartman 1985; Scholes et al. 2005). ${ }^{3}$ We extend this theoretical framework to incorporate the temporary tax holiday and argue that, because the Act does not change the after-local-tax returns to investment, firms likely to repatriate under the Act are those with limited investment opportunities in both the U.S. and abroad. Therefore, distributing the repatriated cash to shareholders is the economically efficient outcome for many firms that benefit from the tax holiday.

Because the nature of the Act is a one-time only tax holiday, we expect that firms are more likely to increase repurchases than dividends. Repurchases are an effective method for distributing a positive transitory shock to cash flow since they do not imply a commitment to make regular distributions (Guay and Harford 2000). Furthermore, unlike dividends, open market repurchases do not require a formal announcement thereby increasing the opacity of shareholder distributions made with repatriated funds.

We test our predictions by investigating the investment opportunities, free cash flows, and payout behavior of firms that disclose their repatriation intentions under the Act. Financial reporting rules require firms considering repatriation under the Act to disclose a summary of the repatriation provision as it applies to the firm, estimates of possible amounts of repatriation, and the related tax effects. ${ }^{4}$ We perform a search of SEC 10-K and 10-Q filings from October 22, 2004 through September 30, 2006 for disclosures of firms’ repatriation plans. Ultimately, we identify 357 firms that repatriate a total of $\$ 291.6$ billion under the Act.

\footnotetext{
${ }^{3}$ Though the theory suggests that only after-tax returns affect the decision to repatriate, this result relies on the assumption that taxes and returns are constant. A large empirical literature finds evidence that taxes affect repatriations (Hines and Hubbard 1990; Desai, Foley, and Hines 2001; Altshuler and Newlon 1993; Grubert 1998) and that this effect relates to inter-temporal changes in tax rates (Altshuler, Newlon and Randolph 1995).

${ }^{4}$ See the Financial Accounting Standards Board Staff Position No. 109-2 (FSP 109-2).
} 
Using a sample of 357 repatriating and 2,339 non-repatriating firms, we find evidence consistent with repatriating firms facing limited investment opportunities. Specifically, we find that the probability that a firm repatriates under the Act is increasing in free cash flows and decreasing in the changes in return on assets and market to book ratio in the years leading up to the Act. If firms that repatriate have limited investment opportunities, then we further expect that repatriating firms will distribute repatriated earnings in an effort to mitigate agency concerns. Although we find evidence that total repurchases across all multinational firms increase in 2005, the mean increase in repurchases for repatriating firms is \$224 million compared to only \$18 million for non-repatriating firms. Using a Compustat (CRSP) measure of repurchases, we estimate that, after controlling for other predictors of repurchases, repatriating firms increase share repurchases during 2005 by $\$ 60.85$ billion ( $\$ 55.80$ billion) more than nonrepatriating firms. ${ }^{5}$ This increase represents 20.87 (19.14) percent of the total amount of repatriations under the Act reported by our sample firms ( $\$ 291.6$ billion).

This study makes three important contributions. First, this paper contributes to our understanding of the effect of the Act on firm behavior, and should be of interest to policy makers. Other studies that investigate the Act focus on the valuation effects of the tax holiday. De Waegenaere and Sansing (2008) model the effects of a tax holiday on the market valuation of foreign earnings reinvested in foreign assets and the related deferred tax liabilities. They show that the value of a foreign subsidiary that repatriates during a tax holiday increases by the amount of tax savings under the holiday. Consistent with the theory in De Waegenaere and Sansing (2008), Oler, Shevlin, and Wilson (2007) find that during the tax holiday, firms' market values increase in the amount of potential tax savings under the Act. In contrast, we investigate the

\footnotetext{
${ }^{5}$ The mean increase in affected firms is 0.205 percent of assets per quarter and the cumulative assets for the affected firms is $\$ 3.340$ trillion.
} 
characteristics of firms that repatriate under the Act and how firms use these funds. We find evidence that, in spite of having plans to invest in approved activities, repatriating firms significantly increase payments to shareholders, and the amount of this increase is related to the amount of repatriation. Although these results suggest that firms are using repatriated funds for a disallowed purpose, the Act does not require a direct tracing of the use of funds. Due to the fungible nature of cash, firms could have made the investments stated in their reinvestment plan, but then used other freed up funds for share repurchases. Though this may in some way violate the intention of the Act, these firms are putting overseas profits back into the U.S. economy just not in the manner that Congress intended. Whether distribution to shareholders is the preferred way to put the funds into the U.S. economy is subject to debate. ${ }^{6}$ Nonetheless, our results provide useful information about how firms respond to a temporary tax holiday.

Second, the results of this study corroborate the evidence in existing studies that find that repatriation taxes are a binding constraint on firms' cash management. For example, Foley, Hartzell, Titman, and Twite (2007) find that repatriation taxes help explain why multinational firms hold excess cash. Consistent with Foley et al. (2007), we find evidence that the reduction of repatriation taxes induces firms with high free cash flows to bring foreign earnings back into the United States. Furthermore, the large response to the tax holiday suggests that strategies to de-facto repatriate using complex organizational structures (e.g., cross-border special purposes entities) do not completely remove the constraint of repatriation taxes on intra-firm cash flows.

Third, we contribute to the literature that investigates whether firms repurchase shares to reduce agency costs of free cash flows (Jensen 1986). In a setting in which theory predicts

\footnotetext{
${ }^{6}$ On one hand, the funds may be more quickly injected into the U.S. economy if they are paid out to shareholders rather than sitting in a corporate account waiting for board approval. On the other hand, if the proceeds from the share repurchases are ultimately deposited into personal savings accounts then, at least in the near-term, the repatriated funds will not lead to incremental spending and, hence, job creation.
} 
agency benefits from repatriation and subsequent distribution to shareholders, we find evidence consistent with the free cash flow hypothesis. Similar to Grullon and Michaely (2004) who examine firm performance and characteristics around share repurchases, the results of this study suggest that firms increase share repurchases to mitigate over-investment. In addition, our work contributes to the debate on how firms use windfall profits/cash flow (Blanchard, Lopez-deSilanes, and Shleifer 1994; Bates 2005). We provide evidence that at least some of the cash brought back into the U.S. is not over-invested but is remitted to shareholders to alleviate potential agency concerns.

The remainder of the paper is organized as follows. Section 2 provides background on tax and accounting rules for foreign subsidiary earnings. Section 3 develops our hypotheses. Section 4 describes the analysis of aggregate Flow of Funds data, Section 5 describes the firmlevel analysis of characteristics of repatriating firms and payout behavior, and Section 6 concludes.

\section{Summary of Repatriation Taxes and the Tax Holiday}

Under U.S. tax law, multinational firms pay taxes on foreign earnings upon repatriation of the earnings to the U.S. at a rate equal to the U.S. tax rate. The U.S. tax liability on dividend repatriations equals the dividend grossed up for foreign taxes paid times the U.S. tax rate. To reduce the potential for double taxation, the firm can decrease the U.S. tax liability by foreign taxes paid. This foreign tax credit is calculated on a world-wide basis for all foreign source income, rather than a country by country basis, and equals the lesser of the amount of foreign taxes paid on foreign income or U.S. taxes on foreign income. Therefore, a firm with an average foreign tax rate greater than the U.S. tax rate generally owes no U.S. taxes on repatriations of 
foreign earnings. A firm with an average foreign tax rate less than the U.S. tax rate generally owes U.S. taxes on repatriated earnings at a rate equal to the difference between the U.S. and foreign tax rates. ${ }^{7}$

The Act was introduced in the House of Representatives on July 25, 2003, in the Senate on September 18, 2003, and eventually signed by President Bush on October 22, 2004. The Act creates a one-time tax incentive for U.S. multinational companies to remit foreign earnings to the U.S. by reducing the U.S. tax rate on repatriations of foreign earnings. This reduced tax rate is structured as an 85 percent dividends received deduction on eligible dividends received from controlled foreign corporations in either 2004 or 2005. Because the maximum U.S. tax rate during this period is 35 percent, the dividends received deduction reduces the maximum tax rate on repatriations to 5.25 percent.

Though the Act originated as a measure to address the World Trade Organization's ruling that export tax incentives in place at the time constituted an illegal export subsidy, Congress added the temporary reduction in repatriation taxes to the bill as a means to increase jobs in the United States. In accordance with this intent, the Act includes restrictions on the amount of funds eligible for the dividends received deduction as well as on the intended use of the funds in the United States.

First, the Act limits the amount eligible for the dividends received deduction to extraordinary dividends, defined as the excess of repatriations during the year over the average amount of repatriations during the previous five years, excluding the highest and lowest years. All else equal, firms that have been systematically repatriating in the past will not benefit as

\footnotetext{
${ }^{7}$ Because the foreign tax credit limitation is calculated on a world-wide basis, firms can use excess credits from high tax rate countries to offset the U.S. tax liability on repatriations from low tax rate countries. The ability to crosscredit creates an incentive to time repatriations from low tax rate countries to coincide with repatriations from high tax rate countries. However, cross-crediting is limited by foreign tax credit baskets based on the type of income. For a more detailed discussion of U.S. taxation of foreign income, see Scholes et al. (2005).
} 
much under the Act as firms that have never repatriated. The Act further limits the eligible dividend amount to the greater of (1) \$500 million, (2) the earnings reported as permanently reinvested on the last audited financial statements filed on or before June 30, 2003, or (3) if the amount of permanently reinvested earnings (PRE) is not reported, the amount of U.S. tax liability attributable to PRE reported in the last audited financial statements filed on or before June 30, 2003, divided by $0.35 .{ }^{8}$ The Act also reduces the amount eligible for the dividends received deduction by any increase in related-party debt incurred by foreign subsidiaries between October 3, 2004 and the close of the tax year for which the firm claims the dividends received deduction.

Second, to be eligible for the dividends received deduction, the dividends must be paid in cash and invested in the U.S. pursuant to a plan which is approved by the chief executive officer or comparable officer and the board of directors and which provides for reinvestment of the dividends in an approved use. Approved uses of the funds include, but are not limited to, funding for hiring and training, infrastructure, research and development, capital investments, and financial stabilization for purposes of job retention and creation. The Act only specifically prohibits using repatriated funds for executive compensation and does not require firms to demonstrate that repatriated funds are used for the purpose stated in the approved plan. ${ }^{9}$ However, subsequent guidance issued by the IRS, Notice 2005-10, lists dividends, share

\footnotetext{
${ }^{8}$ Accounting Principals Board Opinion No. 23 (APB 23) defines PRE as the earnings of foreign subsidiaries that have been invested abroad indefinitely or that will be remitted in a tax-free liquidation. For financial reporting purposes, firms recognize the potential U.S. tax liability on foreign earnings when they report the foreign earnings, regardless of whether they repatriate the earnings to the U.S., resulting in a deferred tax liability in the amount of the potential U.S. taxes on future repatriations. However, if the firm deems the foreign earnings as PRE, it is not required to record a deferred tax liability or recognize income tax expense for the potential U.S. tax liability on future repatriations. If, or when, a firm changes its reinvestment plans and no longer considers the earnings indefinitely reinvested, it records an expense for the U.S. tax liability. See Collins, Hand, and Shackelford (2001) and Krull (2004) for a discussion of firms' decisions to designate foreign earnings as PRE.

${ }^{9}$ The temporary dividends received deduction is established in Internal Revenue Code Section 965. See Blessing (2004) and Stoffregen, Lainoff, and Satkoski (2005) for a more technical discussion of the Section 965 requirements and limitations.
} 
repurchases, tax payments, and purchases of debt instruments or a less-than-ten percent interest in a business entity as additional disallowed uses. The Notice states that tracing uses of the repatriated funds would be too difficult to administer and that there is no requirement that repatriated funds be used to incrementally increase spending for approved uses over amounts spent for those purposes in previous years. ${ }^{10}$

The decision to repatriate foreign earnings under the Act affects firms’ financial statements through its effect on income tax expense and deferred tax liabilities. In the months following the Act, many firms requested additional guidance to clarify the application of the new tax laws including allowable uses of the repatriated funds and the calculation of the foreign tax credit for repatriations eligible for the dividends received deduction. Because the application of the law was unclear, the financial statement effects were also unclear. On December 21, 2004, the Financial Accounting Standards Board (FASB) issued FASB Staff Position No. 109-2 (FSP 109-2) to provide accounting and disclosure guidance for amounts firms intend to repatriate under the Act. FSP 109-2 requires firms that have not yet completed their evaluation of the effect of the Act on their reinvestment plans to disclose a summary of the repatriation provision as it applies to the firm, the effect on income tax expense for any amounts that will be repatriated under the Act, the range of reasonably possible amounts still being considered for repatriation

\footnotetext{
${ }^{10}$ Congress intensely debated the list of approved uses included in the Act and the need to trace whether firms ultimately use the funds for the purpose stated in the approved plan. On May 5, 2004, Senators Breaux and Feinstein introduced an amendment that would limit approved uses to wages, additions to capital accounts for property located within the U.S., research and development, and irrevocable contributions to a qualified employer plan. The amendment also included a provision that would require firms to trace where the money was spent and pay taxes and interest on any amounts not used for qualified expenditures. Senator Breaux defended this measure stating that the amendment “...is about responsibility and accountability, about creating jobs in this country, not stock buybacks that enrich a few at the expense of jobs in this country." (Congressional Record 2004) Opponents criticized the amendment by citing estimates that the tax holiday would generate 660,000 new jobs and stating that the narrow list of approved uses in the amendment would prevent firms from spending repatriated funds for job related expenses such as job training to upgrade skills, worker health, dental and hospital expenses, employee childcare, worker relocation reimbursements, and employee tuition assistance. (Congressional Record 2004b) The amendment was defeated, and the bill eventually enacted contains a non-exclusive list of approved uses but no requirement to trace the use of repatriated funds. See Alexander and Scholz (2008) for a summary of the Act's legislative history.
} 
under the Act, and the range of income tax effects of such repatriation. For the period during which a firm completes its evaluation of the Act, FSP 109-2 requires it to report the total effect on income tax expense (or benefit) for amounts that have been repatriated under the Act.

\section{Theory and Hypotheses}

Hartman (1985) expresses the decision to invest abroad as a function of exogenous and constant foreign and domestic tax rates and risk-adjusted after-tax returns. In the analysis that follows, we first summarize Hartman (1985) then extend this analysis to incorporate the temporary tax holiday. Like Hartman, we assume that foreign and domestic after-tax returns on incremental investment projects, $r f$ and $r d$, are exogenous and constant over time. Thus, any change in taxation on repatriation does not affect the return on the incremental investment opportunity. We also assume that the firm faces a cost of capital, $r^{*}$, which is exogenous and constant over time, and that viable investment projects must return at least the cost of capital, i.e., $r d, r f \geq r^{*}$. We further assume that domestic tax rates are higher than foreign tax rates. Though the converse may hold, firms with foreign tax rates greater than domestic tax rates are less likely to benefit from the reduction in the U.S. tax rate on repatriations.

If a firm invests an amount, $I$, overseas, the investment yields the following accumulation after $n$ periods:

$$
I\left[(1+r f)^{n}-1\right]
$$

where $r f$ equals the risk-adjusted after-local-tax rate of return abroad.

For a firm with foreign earnings on an existing foreign investment, the repatriation decision requires a comparison of the after-all-taxes returns to reinvesting the foreign earnings abroad and repatriating to the United States. Allow EP to represent the cumulative amount of 
foreign earnings on the initial investment (Equation (1)). At the beginning of the next period, the firm decides whether to repatriate the earnings and invest them in the U.S. for n periods or reinvest them in foreign operations and repatriate after $\mathrm{n}$ periods. If the firm repatriates the earnings at the beginning of the period and invests the after-tax amount in the U.S. for n periods, at the end of the investment horizon the firm has:

$$
E P(1+r d)^{n}-\frac{E P}{(1-t f)}(t d-t f)(1+r d)^{n}=\frac{E P(1-t d)}{(1-t f)}(1+r d)^{n},
$$

Where $t d$ equals the domestic tax rate, $t f$ equals the foreign tax rate, $r d$ equals the risk-adjusted after-tax domestic rate of return, and $t d>t f$.

If instead the firm leaves the earnings abroad and then repatriates after $\mathrm{n}$ periods it has:

$$
E P(1+r f)^{n}-\frac{E P}{(1-t f)}(t d-t f)(1+r f)^{n}=\frac{E P(1-t d)}{(1-t f)}(1+r f)^{n} .
$$

A firm will repatriate at the beginning of the period when (2) > (3). ${ }^{11}$ This relation simplifies to a comparison of $r d$ and $r f$. Thus, firms will repatriate foreign earnings when the domestic aftertax rate of return exceeds the foreign after-local-tax return, and the U.S. tax on repatriations does not influence the repatriation decision. (Hartman 1985; Scholes et al. 2005)

Although the theory suggests that repatriation taxes do not affect the repatriation decision, existing studies show that dividend repatriations are sensitive to the tax cost of repatriating (Hines and Hubbard 1990; Altshuler, Newlon, and Randolph 1995; Desai, Foley, and Hines 2001; Altshuler and Newlon 1993; Grubert 1998). These studies argue that tax rates affect repatriations due to a firm's ability to exploit temporary changes in the tax cost of repatriation by timing repatriations from low-tax countries to coincide with repatriations from high-tax countries (Clausing 2005). In this study, we investigate the effect of a temporary change in statutory tax

\footnotetext{
${ }^{11}$ In Equations (2) and (3) EP is grossed up by the foreign tax rate because U.S. firms pay U.S. taxes on their local pre-tax income.
} 
rates on repatriations, which is incremental to intra-firm, inter-temporal variation in the tax cost of repatriations.

We modify the Hartman (1985) analysis by incorporating the temporary effect of the Act on the tax cost of repatriating and by incorporating firms' ability to borrow. The Act allows a temporary 85 percent dividends received deduction for repatriations in 2004 or 2005 . Therefore, the Act changes the decision to reinvest versus repatriate because tax rates are not constant over time: the U.S tax rate on repatriations is lower if the firm repatriates during the tax holiday than if the firm reinvests the profits abroad and repatriates later. We let $t$ do represent the U.S. tax on repatriations that benefit from the tax holiday. ${ }^{12}$ Assuming that repatriations at the beginning of the period benefit from the tax holiday, if the firm repatriates at the beginning of the period then reinvests the after-tax amount in the U.S., at the end of $n$ periods it has:

$$
E P(1+r d)^{n}-\frac{E P}{(1-t f)}(t d o-t f)(1+r d)^{n}=\frac{E P(1-t d o)}{(1-t f)}(1+r d)^{n}
$$

where $t d o<t d$. Notice that (4) is equivalent to (2) with $t d o$ replacing $t d$.

Because the tax holiday is not available when the firm reinvests its profits in the foreign country and repatriates after $\mathrm{n}$ periods, the amount the firm has if it repatriates after $\mathrm{n}$ periods is the same as Equation (3). The firm will repatriate at the beginning of the period as long as (4) > (3). Therefore, the firm will repatriate immediately taking advantage of the tax holiday when:

$$
r d>(1+r f)\left[\frac{(1-t d)}{(1-t d o)}\right]^{\frac{1}{n}}-1
$$

If the firm has an available project, $r d$, that meets the criteria of (5), then it has an incentive to repatriate under the Act. However, an important caveat is that $r d$ must equal or exceed $r *$ for

\footnotetext{
12 The following details the computation of $t d o$.

$E P-\frac{E P}{1-t f}(t d-t f)+\frac{.85 E P}{1-t f}(t d-t f)=E P-\frac{.15 E P(t d-t f)}{1-t f}=\frac{E P(1-.85 t f-.15 t d)}{1-t f}$ So, $t d o=(.85 t f+.15 t d)$
} 
the firm to be willing to repatriate solely to invest in the United States. Said another way, the Act does not change the return on the incremental investment project, $r d$, but rather decreases the cost of repatriating funds. Therefore, existing shareholders receive a wind-fall gain through the increase in value attributable to the decrease in taxes on unremitted earnings previously impounded into price. However, in our model, this increase in value is not accompanied by a decrease in the firm's cost of capital, $r^{*}{ }^{13}$

This caveat is illustrated by the following. Assume that 1) if a firm has an investment opportunity it can borrow at rate $i$ and invest in that project, where $i$ equals the firm-specific after-tax cost of borrowing, and 2) the firm will invest in the project as long as the after-tax return is greater than the after-tax cost of borrowing. ${ }^{14}$ In addition, assume that $i=r^{* 15}$ and that there is no adverse selection component to $i$ or $r *$ Because the firm did not repatriate prior to the Act, when $t d o$ was equal to $t d$, we can infer that $r d<r f$. Furthermore, as the firm did not borrow and invest in the incremental domestic investment opportunity, we can also infer that $r d$ $<i$. Therefore, for a firm to consider repatriating under the Act, the following relation must hold:

$$
i>r d>(1+r f)\left[\frac{(1-t d)}{(1-t d o)}\right]^{\frac{1}{n}}-1
$$

Equation (6) implies that the return on the incremental project, $r d$, is also lower than $r *$.

\footnotetext{
${ }^{13}$ For brevity, we assume that repatriating under the Act does not affect the cost of capital. This follows from our assumption that $r *$ is constant and exogenous. If we relax this assumption and allow repatriation to decrease the cost of capital, then repatriating under the Act will yield more potential investment projects having an $r d$ that exceeds $r^{*}$ thereby spurring investment. However, it is likely that this increase in investment is small relative to the amounts that were repatriated under the Act. Furthermore, the presence of increasing investment opportunities creates a conservative bias in our empirical tests.

${ }^{14} \mathrm{We}$ assume that $i$ is identical across all countries and that the firm always has the option to use its overseas assets to secure its borrowing.

${ }^{15}$ This relation assumes that capital structure is irrelevant to firm value. This relation also assumes that the cost of borrowing, $i$, is exogenous with respect to both the decision to repatriate and the decision to invest in the incremental project, i.e., that $i$ is not dependent upon whether the incremental investment project is situated in the U.S or abroad. Furthermore, $i$ is set independent of the shift in firms' capital structure that results from the borrowing. See Hines (1994) for a full equilibrium model of foreign investment that incorporates capital structure.
} 
Notice that this relation implies that $r d$ is low but not necessarily that $r f$ is below $i$. As the investment horizon increases the term in brackets approaches one. ${ }^{16}$ Therefore, if $r f$ is greater than $i$, the firm will not repatriate but will invest in the foreign country. If $r f$ is less than $i$ then the firm's EP could be trapped overseas, creating an agency problem if this EP is either in cash or over-invested in foreign assets (Jensen 1986). Over-invested funds are, by definition, held in negative NPV projects, i.e. the return on investment is less than the discount rate. ${ }^{17}$ De Waegenaere and Sansing (2008) show that for some firms the cost of holding funds abroad in negative net present value projects is less than the cost of repatriating them, even without the prospect of a tax holiday. Consistent with this theoretical result, Foley, Hartzell, Titman and Twite (2007) find that holdings of cash and cash equivalents in foreign subsidiaries are increasing in the tax cost of repatriation.

We investigate the extent to which repatriations under the Act are motivated by the need to disgorge excess cash trapped abroad. Our theory suggests that firms that take advantage of the tax holiday have limited investment opportunities in both the U.S. and abroad potentially leading to over-investment. That is, the expected return on each incremental project available to the firm is low and so firms that benefit from repatriation face costs associated with excess cash/overinvestment. For these firms, the cost of repatriation under U.S. tax laws in effect before the Act exceeds the cost of over-investment. The tax holiday decreases the cost of repatriation, thus making repatriation cost-effective and creating the opportunity to bring home excess cash abroad. To investigate our conjecture, we test the following hypothesis:

\footnotetext{
${ }^{16}$ Equation (6) does not preclude a firm from investing in a project identified prior to the ACJA but whose logistical requirements led to a time delay which permitted the use of funds ultimately repatriated under the act to fund the project.

17 These funds could be invested in passive assets such as stocks and bonds, in which case the firm can continue to defer the U.S. taxes on these funds but cannot defer U.S. taxes on the earnings from the passive investments.
} 
$\mathrm{H}_{1}$ : The likelihood that a firm repatriates under the Act is increasing in its over-investment concerns as evidenced by limited investment opportunities and high free cash flows.

Firms that benefit from the Act chose not to repatriate before the Act because domestic investment opportunities are limited $(r d \leq r f)$. If domestic opportunities are limited, then repatriation of foreign funds does not eliminate the over-investment problem. When a firm's capital exceeds its investment opportunities, it can over-invest, retain the excess cash, or distribute the cash to its shareholders. Because firms can mitigate agency costs of overinvestment by distributing excess cash to shareholders we predict the following:

$\mathrm{H}_{2 \mathrm{a}}$ : Firms that repatriate under the Act abnormally increase shareholder distributions. Repurchasing stock and paying dividends are the two primary methods for distributing excess capital. However, firms may prefer share repurchases for at least two reasons. First, unlike dividends, open market repurchases do not typically require commitment. Thus, once a firm repurchases, it is not expected to continue to repurchase on a regular basis (Guay and Harford 2000). Second, repurchases are tax-preferred. Though dividends and repurchases are both currently taxed at a 15 percent preferential rate, repurchases are taxed as capital gains, which dominate dividends from a tax perspective. ${ }^{18}$ This leads us to our final hypothesis:

$\mathrm{H}_{2 \mathrm{~b}}$ : Firms that repatriate under the Act abnormally increase share repurchases.

\section{Aggregate Analysis of Repatriations and Shareholder Payouts}

We first analyze the Flow of Funds data published by the Federal Reserve Board to document the effect of the Act on aggregate repatriation behavior relative to repatriations before

\footnotetext{
${ }^{18}$ Capital gains dominate dividends from a tax perspective for at least four reasons. One, dividends accelerate the tax payment that could be deferred until the stock is sold (or fully avoided if held until the shareholder dies). Two, unlike dividends, shareholders can time the sale of an investment and thus pay the resulting capital gain tax when the shareholder's marginal tax rate is lowest. Three, with capital gains a portion of the proceeds is treated as a return of basis and thus goes untaxed. Conversely, basis cannot be used to avoid dividend income. Four, since only $\$ 3,000$ of capital losses (net of capital gains) can be deducted each year, capital gains, unlike dividends, enable individuals to accelerate utilization of their pool of capital losses, an important consideration for many individuals following the downturn in the equity markets from 2000 to 2002.
} 
the Act. The Flow of Funds data reports total dividends received by U.S. corporations from foreign subsidiaries. If firms increase repatriations during the tax holiday we expect a significant increase in dividends received from foreign subsidiaries after the Act. In Figure 1, we plot total dividends received from foreign subsidiaries (i.e., earnings repatriations) for each quarter from 1989 through 2005. Total dividends remains within the range of $\$ 5$ billion to $\$ 15$ billion for most quarters from the first quarter of 1989 through the fourth quarter of 2004, then increases to nearly $\$ 30$ billion in the first quarter of 2005, $\$ 35$ billion in the second quarter, $\$ 74$ billion in the third quarter, and $\$ 65$ billion in the fourth quarter. The mean quarterly dividends from foreign subsidiaries is $\$ 7.44$ billion in 2003 and $\$ 8.98$ billion in 2004, whereas in 2005 the mean quarterly dividends from foreign subsidiaries is $\$ 51.28$ billion, a 471 percent increase from 2004 $(t=3.79)$. As a percentage of gross domestic product (GDP) total dividends from foreign subsidiaries is 0.27 percent in 2003, 0.31 percent in 2004, and 1.63 percent in 2005. Thus, repatriations increase by 1.32 percent of GDP during the tax holiday.

Because we expect that firms that repatriate under the Act increase total payout, and in particular, share repurchases, in Figure 2 we show total quarterly share repurchases and total shareholder dividends from 1989 through 2005. ${ }^{19}$ Both share repurchases and shareholder dividends increase steadily from 1995 through 2005. However, share repurchases begin a sharper increase in 2004 that continues through 2005. The mean quarterly share repurchases increases from $\$ 11.9$ billion in 2003 to $\$ 17.1$ billion in 2004, a 44 percent increase, and increases further to $\$ 28.4$ billion in 2005 , a 66 percent increase. The mean quarterly shareholder dividends

\footnotetext{
${ }^{19}$ As described in Section 5.3, consistent with Fama and French (2001), we measure net repurchases as the change in treasury stock. If there is a net decrease in treasury stock, then we set the repurchases measure equal to zero. For those firms that do not use the treasury stock method, we estimate share repurchases as repurchases of common and preferred stock from the Statement of Cash Flows less the decrease in preferred stock from the Compustat Industrial Quarterly files and shareholder dividends as quarterly dividends per share times total shares outstanding from the Compustat Industrial Quarterly files. Consistent with the procedures we use to construct the sample in Section 5, we eliminate observations in the top 0.5 percent of dividends and share repurchases.
} 
increases from $\$ 11.8$ billion in 2003 to $\$ 13.7$ billion in 2004, a 16 percent increase, and increases further to $\$ 15.3$ billion in 2005, a 12 percent increase. The increase in share repurchases from 2004 to 2005 is statistically significant ( $t=4.41)$, but the increase in dividends is not significant $(\mathrm{t}=1.15) .^{20}$

Based on the aggregate data, dividends from foreign subsidiaries increase significantly after the Act. Share repurchases and shareholder dividends also increase significantly after the Act. However aggregate share repurchases and shareholder dividends include amounts for all firms regardless of whether they repatriate under the Act. Therefore, to formally investigate repatriation behavior around the Act, we use firm-level data to study characteristics of repatriating firms and whether changes in payout behavior differ between firms that repatriate under the Act and those that do not repatriate.

\section{Firm-Level Analysis of Repatriation Plans and Shareholder Payouts}

To investigate characteristics of repatriating firms and changes in payout behavior for repatriating versus non-repatriating firms, we construct a sample using the population of firms on Compustat with non-missing world-wide assets (Compustat data6) for 2001 through 2005 and non-missing foreign activity for the last three years. ${ }^{21}$ From this sample, we eliminate firms with negative book values, firms incorporated outside of the U.S., and all insurance companies and financial services firms. We then review firms' FSP 109-2 disclosures about the financial statement effects of the Act to study the relation between repatriations under the Act and firms'

\footnotetext{
${ }^{20}$ At least some portion of the increase in repurchases and dividends in our event period is attributable to the 2003 reduction in dividends and capital gains tax rates. However, we document a sharper increase in repurchases that corresponds more closely with the timing of the American Jobs Creation Act of 2004 than the Jobs and Growth Tax Relief Reconciliation Act of 2003. In our multivariate tests, we include a measure of changes in dividend and capital gain tax rates to control for the effect of this tax rate change on share repurchases.

${ }^{21}$ We eliminate firms that are missing foreign tax expense or foreign pre-tax earnings on Compustat in each of the prior three years.
} 
payout behavior. ${ }^{22}$ In the resulting sample of 2,696 firms that mention the Act in their SEC reports, 357 repatriate under the Act in 2004 or 2005, and 2,339 state that they will not repatriate under the Act or do not mention the tax holiday.

\subsection{DESCRIPTIVE STATISTICS}

We report summary statistics by repatriation intentions (repatriating or non-repatriating) in Table 1. Firms in the repatriating sample are larger on average than firms in the nonrepatriating sample in terms of world-wide assets and market value. At the end of 2004, the mean world-wide assets for the repatriating sample is $\$ 15.383$ billion and the mean market value of equity is $\$ 14.802$ billion, whereas the mean world-wide assets for the non-repatriating sample is $\$ 2.449$ billion and the mean market value of equity is $\$ 2.086$ billion. The repatriating sample has a lower mean cash to asset ratio (0.177) than the non-repatriating sample (0.228). The mean effective tax rate of the repatriating sample (0.294) is higher than the mean effective tax rate of the non-repatriating sample (0.231) suggesting that the repatriating sample faces a greater tax burden. For the repatriating sample, the mean amount the firms plan to or have repatriated (Total Repatriation) is $\$ 833.14$ million.

Table 2 uses the Fama and French (1997) industry classifications to show the industry composition and ratio of cash to assets for repatriating and non-repatriating firms as of the end of 2004. Chips represents the greatest industry concentration in the repatriating sample whereas Business Services is the largest category in the non-repatriating sample. We also report the ratio of Total Repatriation to Cash (Rep/Cash) for the repatriating firms. The mean cash to asset ratio is 0.18 for repatriating firms and 0.23 for non-repatriating firms. This higher ratio of cash to assets for non-repatriating firms suggests that the decision to repatriate is affected by more than

\footnotetext{
${ }^{22}$ See Section 2 for a detailed description of the disclosure requirements.
} 
merely having large amounts of cash. Notably, anticipated repatriations reported by repatriating firms are more than 1.5 times the cash and short-term securities reported by these firms as of the end of $2004 .^{23}$

\subsection{CHARACTERISTICS OF REPATRIATING FIRMS}

Our theory predicts that the firms that benefit from the Act are those that face costs associated with over-investment. Grullon and Michaely (2004) suggest that agency problems attributable to over-investment arise when firms transition from a high-growth to a low-growth stage. As growth opportunities diminish, free cash flows increase, and the likelihood of overinvestment by management increases. Thus, these firms exhibit decreases in capital investment (R\&D and capital expenditures) and increases in free cash flows. In the context of this study, we expect that firms that benefit from repatriating under the Act, and therefore decide to repatriate, are firms for which growth opportunities in both the U.S. and abroad are decreasing prior to the Act. Therefore, we anticipate that repatriating firms experience decreases in the returns to incremental investment, declines in capital investment and growth, and increases in free-cash flow in the years leading up to the Act. To test this prediction, we estimate the following equation using logistic regression:

$$
\begin{aligned}
& \text { Repatriate }=\alpha_{0}+\alpha_{1} \Delta F P T I+\alpha_{2} \Delta R O A+\alpha_{3} \Delta M B+\alpha_{4} \Delta R D+\alpha_{5} \Delta C a p E x+\alpha_{6} F C F \\
& +\alpha_{7} \text { RateDum }+\alpha_{8} \text { USTR }+\alpha_{9} \% \text { FAssets }
\end{aligned}
$$

Where Repatriate equals one if the firm states that it will repatriate (357 firms), and zero otherwise (2,339 firms) and each of the change variables $(\Delta)$ is the mean of the change in the

\footnotetext{
${ }^{23}$ For illustrative purposes, consider Pfizer. In its 2005 financial statements, Pfizer disclosed that it planned to repatriate $\$ 37$ billion under the provisions of the Act. However, its reported total cash and short-term investments was $\$ 19.893$ (\$22.226) billion as of the end of 2004 (2005).
} 
firm's measure from 2002 to $2004 .{ }^{24} \Delta R O A$ equals the change in net income scaled by average world-wide assets; $\triangle F P T I$ equals the change in foreign pre-tax income scaled by average worldwide assets; $\triangle M B$ equals the change in the firm's market to book value ratio; $\triangle R D$ equals the change in the ratio of $\mathrm{R} \& \mathrm{D}$ to average world-wide assets; $\triangle C a p E x$ equals the change in capital expenditures divided by average world-wide assets; FCF equals average operating cash flows divided by average world-wide assets from 2002 to 2004; RateDum equals one if the U.S. statutory rate of 0.35 exceeds the average foreign tax rate from 2002 through 2004, and zero otherwise; USTR equals the average U.S. tax rate from 2002 through 2004; \%FAssets equals the ratio of foreign assets to average world-wide assets. ${ }^{25}$

All variables, with the exception of RateDum, \%FAssets, and the numerator in $\triangle F P T I$, use world-wide consolidated information. The use of world-wide consolidated information represents a limitation in our data because we are not able, in general, to distinguish changes in foreign activity from changes in domestic activity. However, our theory predicts that investment opportunities are limited in both the U.S. and abroad. Therefore, the consolidated measures test the combined effect of foreign and domestic investment opportunities on the probability that a firm repatriates under the Act. As a robustness test, we estimate foreign return on assets and domestic return on assets separately for a sub-set of firms in our sample that report foreign segment sales, and estimate Equation (7) using these measures in place of $\triangle F P T I$ and $\triangle R O A$.

\footnotetext{
${ }^{24}$ In calculating the average of the continuous variables from 2002 through 2004, we winsorize firm-year observations at the top and bottom $0.5 \%$.

${ }^{25}$ Because few firms report foreign assets in the segment detail, we estimate foreign assets using the method described in Oler et al. (2007). Oler et al. (2007) decompose ROA into the product of the profit margin (Net Income/Sales) and the asset turnover ratio (Sales/Assets). Using foreign segment sales and assuming the asset turnover ratio is the same for domestic and foreign operations we can solve for foreign assets. In our main tests, we assume foreign assets equals zero for firms that do not report foreign segment sales. This allows us to include all of our 357 repatriating firms in the analysis. To control for the possibility that firms that do not report foreign segment sales have smaller foreign operations and are therefore less likely to repatriate, we repeat our main tests using only firms that report foreign segment sales.
} 
$\mathrm{H}_{1}$ predicts that the probability that a firm repatriates under the Act is higher for firms with limited investment opportunities in both the U.S. and abroad. To determine whether a firm has limited investment opportunities, we are interested in its incremental investment opportunities. The current period level of earnings as a percentage of assets includes earnings from previous, more profitable investments. However, if returns on incremental investments are low, this ratio will be decreasing as the firm makes investments in less profitable opportunities. Therefore, we study the change in earnings as a percentage of assets for foreign operations and the consolidated entity, $\triangle F P T I$ and $\triangle R O A$, to test whether firms' investment opportunities are limited. We expect negative coefficients on both of these variables. ${ }^{26} \Delta M B$ measures changes in investors' expectations about the firm’s investment opportunities. Because market-to-book ratios are increasing in investment opportunities, we expect a negative coefficient on $\triangle M B$. $\triangle R D$ and $\triangle C a p E x$ measure changes in investment activity prior to the Act. We predict negative coefficients on these variables because we anticipate that repatriating firms experience decreases in investment opportunities in the years leading up to the Act. As we anticipate that repatriating firms have higher free cash flows than non-repatriating firms, we expect a positive coefficient on FCF. We include RateDum and USTR to capture the potential tax benefits of repatriating under the Act. Since firms with foreign tax rates greater than the U.S. tax rate generally do not benefit from the Act, we predict a positive coefficient on RateDum. USTR captures the firm's domestic tax burden. We anticipate a positive coefficient on this variable because firms with greater tax burdens will likely receive greater tax savings from repatriation under the Act. Finally, we include \%FAssets to control for the size of foreign operations relative to the consolidated entity.

\footnotetext{
${ }^{26}$ We deflate foreign earnings by average world-wide assets in our main tests because we would have to set this ratio to zero for firms that do not report foreign segment sales introducing a great deal of noise into the measure. We test the effect of changes in the ratio of foreign earnings to foreign assets and domestic earnings to domestic assets in a sensitivity test.
} 
We expect that firms with larger foreign operations are more likely to have funds available to repatriate under the Act and therefore expect a positive coefficient on this variable.

Table 3 Panel A reports summary statistics for the variables in Equation (7) using the full sample of 357 repatriating and 2,339 non-repatriating firms. Mean repatriations as a percentage of world-wide assets is 11.6 percent. ${ }^{27}$ Consistent with our prediction that repatriating firms have lower investment opportunities than non-repatriating firms, the mean $\triangle F P T I$ and $\triangle R O A$ are significantly lower for repatriating firms ( 0.001 and 0.009 , respectively) than for non-repatriating firms (0.011 and 0.017 , respectively). Likewise, the mean $\triangle M B$ is significantly smaller for repatriating firms (-0.218) than for non-repatriating firms (0.077). Also consistent with our prediction, FCF is significantly higher for repatriating firms (0.120) than non-repatriating firms (0.054). However, inconsistent with our expectation that repatriating firms face decreasing capital investment, $\triangle R D$ and $\triangle C a p E x$ are not significantly smaller for repatriating firms than for non-repatriating firms. The mean $\Delta R D$ is $-0.001(-0.000)$ for repatriating (non-repatriating) firms. The mean $\triangle C a p E x$ is -0.004 for repatriating firms and -0.003 for non-repatriating firms. Table 3 Panel B reports the univariate statistics for the 336 repatriating and 1,126 nonrepatriating firms that report geographic segment sales. The only obvious difference between Panel A and Panel B is that \%FAssets more than doubles for the non-repatriating sample (from 20.2 percent to 46.2 percent). All other comparisons across repatriating and non-repatriating firms are similar to Panel A. Thus, the results in Table 3 provide preliminary evidence that repatriating firms have lower investment opportunities and higher free cash flows than nonrepatriating firms.

\footnotetext{
${ }^{27}$ Seven firms in our sample state that they repatriate under the Act but do not report the amount of repatriation.
} 
We report the tests of $\mathrm{H}_{1}$ in Table 4 Panel A. In Column (1) we report the results of estimating Equation (7). Consistent with our hypothesis that the likelihood that a firm repatriates under the Act is higher for firms with limited investment opportunities, the coefficients on $\triangle F P T I$ and $\triangle R O A$ are negative and significant. Also consistent with $\mathrm{H}_{1}$, the coefficient on $\triangle M B$ is negative and significant. Because the market to book ratio represents investors' expectations about the future earnings of the firm, this result suggests that the likelihood of repatriation increases when the market anticipates declining investment opportunities. The coefficient on FCF is positive and significant consistent with $\mathrm{H}_{1}$ suggesting that the probability of repatriation is increasing in free cash flows. However, the coefficients on $\triangle R D$ and $\triangle C a p E x$ are insignificant, inconsistent with $\mathrm{H}_{1}$. The coefficient on \%FAssets is positive and significant, consistent with larger foreign operations yielding more earnings to repatriate.

In Columns (2) and (3) of Table 4, we estimate Equation (7) using a Tobit analysis with Total Repatriation divided by world-wide assets and Total Repatriation divided by lagged PRE as the dependent variables, respectively. The results are similar to those in Column (1) and suggest that the amount that firms repatriate under the Act is increasing in their over-investment concerns. ${ }^{28}$

To further ensure that our results are not driven by differences in the size of foreign operations, in Table 4 Panel B we estimate Equation (7) using only firms that report foreign segment sales. This data screen results in a sample of 1,462 firms with 336 repatriating firms and 1,126 non-repatriating firms. Results are consistent with those in Panel A. In Panel A, we

\footnotetext{
${ }^{28}$ When we include the level of FPTI (scaled by world-wide assets) as a control for the size of foreign operations, inferences are unchanged. Results are also similar when we include world-wide assets as a control for size as in Grullon and Michaely (2004) and when we include the market-to-book ratio. However, in each of these tests, the coefficient on $\triangle M B$ becomes insignificant. In addition, results are similar when we replace USTR and RateDum with TaxBurden, defined as (max\{U.S. taxes on foreign earnings (data273*0.35 less foreign taxes already paid(data64)), zero\}), from Foley et al. (2007). Results are also not sensitive to including controls for the firm's industry.
} 
include $\triangle F P T I$, foreign pre-tax income divided by world-wide assets, to test whether firms with decreasing returns are more likely to repatriate. Because we deflate by world-wide assets, this variable is a potentially noisy measure of the foreign return on assets. For the sample used in Panel B, we can calculate foreign and domestic assets for 1,372 observations. In Column (3) we replace $\triangle F P T I$ and $\triangle R O A$ with $\triangle F R O A$ (the change in foreign return on assets) and $\triangle U S R O A$ (the change in domestic return on assets). Consistent with $\mathrm{H}_{1}$, the coefficients on each of these variables are negative and significant suggesting that firms with limited investment opportunities in both the U.S. and abroad, measured as decreasing returns to domestic and foreign investment, are more likely to repatriate during the tax holiday. Overall, the results in Tables 3 and 4 are consistent with the hypothesis that the probability of repatriation under the Act is increasing in firms’ over-investment concerns. Next, we investigate whether repatriating firms attempt to mitigate this agency cost by distributing repatriated funds.

\subsection{UNIVARIATE ANALYSIS OF CHANGES IN PAYOUT BEHAVIOR}

In Tables 5 and 6 we compare quarterly share repurchases and shareholder dividends for the repatriating and non-repatriating samples. Table 5 reports the mean ratio of share repurchases to world-wide assets (ShrRep) and the total dollar amount of repurchases (Total Repurchases) by quarter beginning with the first quarter of 2003 through the fourth quarter of 2005 for the two sub-samples. Consistent with Fama and French (2001), we measure net repurchases as the change in treasury stock. If there is a net decrease in treasury stock, then we set repurchases equal to zero. For those firms that do not use the treasury stock method, we measure net repurchases as total repurchases from the statement of cash flows less decreases in preferred stock. 
The repatriating sample has larger ShrRep than the non-repatriating sample. For the repatriating sample, ShrRep increases from 2.28 percent of assets in 2003, to 2.96 percent of assets in 2004, and 4.32 percent of assets in 2005, an increase in total repurchases of 2.04 percent of assets from 2003 to 2005. For firms in the non-repatriating sample, ShrRep increases from 0.97 percent of assets in 2003 to 1.35 percent of assets in 2004 and 1.75 percent of assets in 2005, an increase in share repurchases of 0.78 percent of assets from 2003 to 2005 . This increase in repurchase activity for repatriating firms is consistent with an increase in payout behavior for firms planning to repatriate under the Act.

We investigate the dividend behavior of firms in the repatriating and non-repatriating samples in order to determine whether all payouts to shareholders generally increase over the period. In Table 6 we report the mean ratio of dividends to world-wide assets (Dividends) and Total Dividends for each sub-sample. We estimate dividends as quarterly dividends per share times the number of shares outstanding from the Compustat Industrial Quarterly files. Increases in dividends are more modest than the increases in repurchases. For the repatriating sample, Dividends increases from 1.29 percent of assets in 2003, to 1.61 percent of assets in 2004, and then decreases to 1.57 percent of assets in 2005, an increase in dividends of 0.28 percent of assets from 2003 to 2005. For the non-repatriating sample, Dividends increases from 1.51 percent of assets in 2003 to 1.63 percent of assets in 2004 and 2.11 percent of assets in 2005, an increase in total dividends of 0.60 percent of assets. Overall, the results in Tables 5 and 6 suggest that repatriating firms increase repurchases relative to non-repatriating firms but do not systematically increase dividends after the Act.

\subsection{MULTIVARIATE TESTS OF CHANGES IN PAYOUT BEHAVIOR}


We formally test whether changes in payout behavior are related to repatriations under the Act using the following empirical model ${ }^{29}$ :

$$
\begin{aligned}
& \text { SPayout }_{i, \mathrm{t}}=\beta_{0}+\beta_{1} \text { PostAct }_{\mathrm{i}, \mathrm{t}}+\beta_{2} \text { Repatriate }_{\mathrm{i}, \mathrm{t}}+\beta_{3} \text { PostAct*Repatriate }_{\mathrm{i}, \mathrm{t}} \\
& +\beta_{4} \text { Size }_{\mathrm{i}, \mathrm{t}-1}+\beta_{5} \Delta \text { CapEX }_{\mathrm{i}, \mathrm{t}-1}+\beta_{6} \Delta R O A_{\mathrm{i}, \mathrm{t}}+\beta_{7} \text { ROA }_{\mathrm{i}, \mathrm{t}}+\beta_{8} \text { Debt }_{\mathrm{i}, \mathrm{t}-1}+\beta_{9} \text { DivYld }_{\mathrm{i}, \mathrm{t}-1} \\
& +\beta_{10} \Delta \text { Cash }_{\mathrm{i}, \mathrm{t}-1}+\beta_{11} \text { PPenalty }_{\mathrm{t}}+\beta_{12} \Delta \text { Payout }_{\mathrm{i}, \mathrm{t}-4}+\gamma_{\mathrm{k}} \text { Industry }_{\mathrm{i}, \mathrm{k}}+\theta_{\mathrm{q}} \text { Ptr }_{\mathrm{i}, \mathrm{q}}+\mathrm{e}_{\mathrm{i}}
\end{aligned}
$$

Where $\triangle P$ ayout equals the change in total dividends plus net share repurchases divided by world-wide assets from quarter t-4 to quarter t; PostAct is a dummy variable equal to one for all quarters beginning after the Act (i.e., the four quarters during 2005) and zero otherwise;

Repatriate is a dummy variable equal to one for firms that state that they will repatriate under the Act, and zero otherwise; Size equals the log of market value of equity at the beginning of the quarter; $\triangle C a p E x$ equals the change in the ratio of capital expenditures to world-wide assets from the beginning of quarter $\mathrm{t}-4$ to the beginning of quarter $\mathrm{t} ; \triangle R O A$ equals the change in the ratio of earnings to average world-wide assets from quarter $\mathrm{t}-1$ to quarter $\mathrm{t}$; $R O A$ equals the ratio of annualized earnings to average world-wide assets in the current quarter. Debt equals the ratio of current plus long term debt to world-wide assets as of the beginning of the quarter; DivYld equals dividends per share divided by stock price at the end of the quarter; $\Delta$ Cash equals the change in the ratio of cash and cash equivalents to world-wide assets from the beginning of quarter t-4 to the beginning of quarter $\mathrm{t}$; $\Delta$ Penalty equals the change in the dividend tax penalty from quarter $\mathrm{t}$ 4 to quarter t; the dividend tax penalty equals the dividend tax rate minus the capital gain tax rate divided by one minus the capital gain tax rate from Poterba and Summers (1985); and Industry and Qtr are fixed effects.

\footnotetext{
${ }^{29}$ Core, Guay, Richardson, and Verdi (2006) and Hribar, Jenkins, and Johnson (2006) use similar models to predict repurchase behavior.
} 
The coefficient on PostAct measures whether changes in payout increase after the Act, and the coefficient on Repatriate measures whether changes are higher for repatriating firms than non-repatriating firms. We make no prediction for these coefficients. However, $\mathrm{H}_{2 \mathrm{a}}$ predicts that repatriating firms increase payout more than non-repatriating firms after the Act. Therefore, we expect a positive coefficient on PostAct*Repatriate $\left(\beta_{3}\right)$.

$\mathrm{H}_{2 b}$ predicts that because share repurchases, unlike dividend payments, do not require a commitment to make ongoing distributions, firms will prefer share repurchases to dividend payments as a means of distributing repatriated funds to shareholders. Thus, we expect that repatriating firms' share repurchases increase more than dividend payments after the Act. To test $\mathrm{H}_{2 \mathrm{~b}}$, we estimate Equation (8) using $\Delta S h r R e p$, the change in the ratio of share repurchases to world-wide assets from quarter t-4 to quarter $\mathrm{t}$, and $\Delta$ Dividends, the change in the ratio of dividends to world-wide assets from quarter t-4 to quarter $\mathrm{t}$, in turn as the dependent variable. We expect a positive coefficient on PostAct*Repatriate when $\Delta$ ShrRep is the dependent variable. Furthermore, we anticipate that $\beta_{3}$ is lower in magnitude when $\Delta$ Dividends is the dependent variable relative to when $\Delta$ ShrRep is the dependent variable.

We also include variables that existing research finds to be significant determinants of repurchases and dividends. Dittmar (2000) predicts that firms are more likely to repurchase shares when the stock is undervalued and information asymmetry is high. Because Vermaelen (1981) predicts that information asymmetry between managers and investors is higher for small firms, Dittmar (2000) predicts that repurchases are decreasing in firm size. However, Dittmar (2000) and Core, Guay, Richardson, and Verdi (2006) find a positive relation between repurchases and size, and Barclay, Smith, and Watts (1995) find a positive relation between dividends and size. We expect a positive coefficient on Size because existing empirical evidence 
suggests that large firms tend to make larger repurchases and pay more dividends. Existing studies show that dividends and repurchases are increasing in profitability (Lintner 1956, Skinner 2008). To control for this effect, we include $\triangle R O A$ and $R O A$. We expect a positive coefficient on $R O A$ but make no prediction for the coefficient on $\triangle R O A$. Consistent with Dittmar (2000) and Core et al. (2006) we expect Debt and $\triangle C a p E x$ to be negatively related to repurchases. Because we anticipate that shareholder payouts are increasing in the cash available for repurchases and dividends, we expect a positive coefficient on $\triangle$ Cash. In addition, we include DivYld as a measure of a firm's capacity to increase dividends. Firms with higher dividend yield have less ability to increase dividends. DivYld also controls for the substitutability of dividends and repurchases (Grullon and Michaely 2002). We make no prediction for the coefficient on DivYld when $\triangle$ Payout or $\triangle$ ShrRep is the dependent variable because it is unclear whether dividends are a substitute or complement for repurchases. However, we expect DivYld to be negatively related to $\Delta$ Dividends. $\triangle$ Penalty controls for the effect of dividend and capital gain tax rates on dividends and share repurchases. We expect the dividend tax penalty to be positively related to share repurchases and negatively related to dividends. Finally, the lagged values of changes in the payout measures control for changes in payout levels before the Act, and we expect negative coefficients on these variables.

Table 7 reports the descriptive statistics by quarter for our sample of 2,696 firms. The mean log of market value of equity for this sample (Size) ranges from 5.652 to 5.681 across the four quarters. The mean change in repurchases as a percent of assets ranges from 0.027 percent to 0.037 percent and the mean change in dividends as a percent of assets ranges from 0.001 to 0.004 percent.

Table 8 includes the results from estimating Equation (8), the OLS estimation of the 
relation between repatriation plans and changes in payout behavior. In Panel A, we report the results using Compustat estimates of $\Delta$ Payout, $\Delta$ Dividends, and $\Delta$ ShrRep. ${ }^{30}$ In Column (1), where $\triangle$ Payout is the dependent variable, the coefficient on PostAct is positive and significant, indicating that payout levels generally increase during 2005 consistent with Figure 2. The coefficient on Repatriate is negative and significant, indicating that repatriating firms have significantly lower changes in payout before the Act than non-repatriating firms. Consistent with $\mathrm{H}_{2 \mathrm{a}}$, the coefficient on PostAct*Repatriate is positive and significant $\left(\beta_{3}=0.00281 ; \mathrm{t}=4.44\right)$. This result is consistent with our expectation that firms that repatriate under the Act have larger increases in payout after the Act than firms that do not repatriate.

In Columns (2) and (3) of Table 8 we decompose $\triangle$ Payout into changes in dividends and changes in share repurchases. In Column (2) we report the results using changes in dividends, ¿Dividends, as the dependent variable. As in Column (1), the coefficient on PostAct is positive and significant, and the coefficient on Repatriate is negative but insignificant. The positive and insignificant coefficient on PostAct*Repatriate $\left(\beta_{3}=0.00004\right.$; $\left.\mathrm{t}=0.27\right)$ suggests that firms that repatriate under the Act do not significantly change their dividend policy around the Act.

When $\Delta$ ShrRep is the dependent variable (Column (3)), the coefficient on PostAct is positive and significant and the coefficient on Repatriate is negative and significant. The positive and significant coefficient on PostAct*Repatriate $\left(\beta_{3}=0.00277 ; \mathrm{t}=4.28\right)$ is consistent with $\mathrm{H}_{2 \mathrm{~b}}{ }^{31}$ This result suggests that firms that repatriate under the Act increase share repurchases after the Act by 0.277 percent of world-wide assets more per quarter during 2005

\footnotetext{
${ }^{30}$ All t-statistics are calculated using the Newey-West procedure to correct for heteroskedasticity and serial correlation. Results are similar when we calculate standard errors clustered by firm or time.

${ }^{31}$ In additional tests we include measures of stock option exercises to control for the possibility that firms repurchase shares to offset the dilutive effect of option exercises (Dittmar 2000). The coefficient on the stock option measure is not significant and including this variable does not affect inferences related to the variables of interest. We also include the market to book ratio as an additional control and find similar results. Results are also similar if we replace $\triangle$ Cash with FCF as defined in Table 3.
} 
than non-repatriating firms. We also estimate Equation (8) using the ratio of the amount repatriated to world-wide assets in place of Repatriate and report the results in Column (4) of Table 8. We find that the increase in repurchases for repatriating firms after the Act is positively related to the amount the firm plans to repatriate. ${ }^{32}$ Overall, the results suggest that repatriating firms increase payout to shareholders after the Act by a larger amount than non-repatriating firms, and the increase in payout results from an increase in share repurchases.

To determine the economic significance of the effect of the Act on share repurchases, we multiply the coefficient on PostAct*Repatriate in Column (3) of Table 8 Panel A (0.00277) by the world-wide assets of the 357 firms that state that they plan to repatriate (\$5.492 trillion) yielding the mean increase in repurchases per quarter for the four quarters of 2005. This estimate suggests that repatriating firms increase net repurchases in 2005 by $\$ 60.85$ billion more than non-repatriating firms $[(0.00277 * \$ 5,492 * 4)]$. This figure represents 20.87 percent of the total maximum amount of repatriations reported by the sample firms ( $\$ 291.6$ billion). However, we use only four quarters after the Act to estimate the coefficient on PostAct*Repatriate. Most firms have not yet completed spending the repatriated funds by the end of $2005 .{ }^{33}$ Therefore, this estimate is likely understated.

The results for the control variables in Table 8 are mixed. Consistent with our expectations and existing literature, the coefficient on Size is positive and significant when $\triangle$ Payout or $\triangle$ ShrRep is the dependent variable, but is negative and significant when $\triangle$ Dividends is the dependent variable. The coefficient on $\triangle \mathrm{CapEx}$ is negative as predicted, but is not significant. Consistent with our predictions, the coefficient on Debt is negative and significant

\footnotetext{
${ }^{32}$ Seven firms in our sample state that they repatriated under the Act, but do not provide an amount. When we eliminate these firms, the coefficient on PostAct*MaxRep is 0.0194 .

${ }^{33}$ Redmiles (2008) suggests that $50 \%$ (70\%) of the firms repatriating will have completed their investment of the repatriated funds by the end of 2006 (2007).
} 
and the coefficient on $\triangle$ Cash is positive and significant for all payout measures. However, this finding is different from the results in Core et al. (2006) who find no significant relation between repurchases and cash holdings. The coefficient on $\triangle R O A$ is negative and significant and the coefficient on ROA is positive and significant for all payout measures. The coefficient on DivYld is negative and significant when $\triangle P$ Payout or $\triangle S h r R e p$ is the dependent variable, consistent with a substitution effect. The coefficient on $\Delta$ Penalty is negative and significant when $\Delta$ Dividends is the dependent variable and positive and significant when $\Delta S h r R e p$ is the dependent variable, consistent with firms paying out more repurchases and less dividends when dividends are taxed at a higher rate relative to capital gains.

In Panel B of Table 8, we re-estimate Equation (8) using CRSP measures of $\triangle$ Payout, ADividends, and $\Delta$ ShrRep as the dependent variable. ${ }^{34}$ The results in Panel B are also consistent with our hypotheses. The coefficient on PostAct*Repatriate is positive and significant for $\triangle$ Payout $\left(\beta_{3}=0.00267 ; \mathrm{t}=3.93\right)$ and for $\Delta \operatorname{ShrRep}\left(\beta_{3}=0.00254 ; \mathrm{t}=4.23\right)$ suggesting that repatriating firms increase repurchases after the Act by 0.254 percent of world-wide assets ( $\$ 55.80$ billion) more than non-repatriating firms. Thus, we estimate that 19.14 percent of the total repatriations reported by the sample firms $[(0.00254 * \$ 5,492 * 4) / \$ 291.6]$ are distributed as repurchases. Also consistent with the results in Panel $\mathrm{A}$, when $\Delta$ Dividends is the dependent variable, the coefficient on PostAct ${ }^{*}$ Repatriate is not significant $\left(\beta_{3}=0.00017 ; \mathrm{t}=1.21\right)$, consistent with the prediction that firms increase share repurchases after the Act but do not significantly change their dividend policy.

\footnotetext{
${ }^{34}$ We estimate $\Delta$ ShrRep using CRSP data by multiplying monthly decreases in shares outstanding by the end of the month stock price. We make corrections as described in Pontiff and Woodgate (2005) to eliminate repurchases attributable to errors in the CRSP data.
} 


\subsection{SENSITIVITY TESTS}

Because the dependent variable of interest in our model, Repatriate, is a choice variable, our results potentially suffer from self-selection bias. Specifically, large, stable, profitable firms are more likely to repurchase shares because they have more free cash flow. These firms are also more likely to have large foreign operations and therefore more likely to repatriate under the Act. Our empirical specification uses a difference in differences approach which should mitigate this potential bias: The main effect for Repatriate controls for whether firms that repatriate have larger changes in repurchases over time, and PostAct*Repatriate tests whether, after controlling for other determinants of repurchases, repatriating firms have larger changes in repurchases after the Act than non-repatriating firms.

To further control for potential self-selection bias, we use a two step estimation procedure (Heckman 1979). We first estimate Equation (7) using a Probit regression. Because we use this procedure to correct for the possibility that large, profitable firms are both more likely to repatriate and more likely to repurchase shares, we also include world-wide assets, the average foreign pre-tax earnings divided by world-wide assets from 2001 to 2004, and the average consolidated return on assets from 2001 through 2004 in the probit equation. From this estimation we calculate the inverse Mills ratio and add it as an additional variable in Equation (8). Because we only observe the repatriation decision in 2005, we estimate Equation (8) using annual data for 2005.

We report the results of this two step procedure in Table 9. In this specification, the coefficient on Repatriate in Panel B tests whether firms that repatriate under the Act have larger changes in repurchases from 2004 to 2005 than non-repatriating firms. After correcting standard errors for correlation in errors between the two equations (Maddala 1983), we find that the 
coefficient on Repatriate is $0.00978(\mathrm{z}=2.15)$. This result suggests that 18.4 percent of the total amount of repatriations reported by the sample firms are distributed as repurchases [(0.00978*5,492)/291.6]. Thus, we find similar results after correcting for self-selection bias.

Another alternative explanation for our results stems from Skinner’s (2008) finding that, over time, share repurchases are both increasing and replacing dividends as a method of paying out corporate cash to shareholders. He also finds that more profitable firms make larger payouts to shareholders. These empirical observations suggest that our results can be explained by firms merely increasing their payout in conjunction with earnings increases. We control for this issue in our primary model by including Size, $\triangle R O A$, and $R O A$. However, to further test whether our results can be explained by earnings changes, we calculate abnormal share repurchases based on a firm-specific payout ratio. We calculate the firm-specific payout ratio by estimating the following relation by firm using years $\mathrm{t}-5$ through $\mathrm{t}-1$ :

$$
\Delta \text { Payout }_{t}=\gamma_{0}+\gamma_{1} R_{\text {OA }}+\gamma_{2} \text { Payout }_{t-1}+\eta_{t} \text {, }
$$

where all variables are defined as in Equation (8) (Lintner 1956). We calculate abnormal changes in payout as the current-year change in payout minus the predicted value from Equation (9). We repeat the same process using share repurchases to estimate abnormal changes in share repurchases. By using only the previous five years to estimate target payout ratios, we control for increases in share repurchases over time. By estimating firm-specific target payout ratios, we control for the possibility that increases in profitability explain our results.

We report the results using abnormal changes in share repurchases and abnormal changes in payout as the dependent variable in Table 10 Columns (1) and (2). In both columns, the coefficient on PostAct*Repatriate is positive and significant. In Column (1), the coefficient on PostAct*Repatriate using abnormal changes in share repurchases as the dependent variable is 
0.00219 which suggests that 16.5 percent of the total amount of repatriations reported by the sample firms are distributed as repurchases $[(0.00219 * \$ 5,492 * 4) / \$ 291.6]$. Thus, we find similar results after controlling for increases in repurchases over time and firm-specific target payout ratios. In untabulated results, we estimate abnormal changes in repurchases and payout using the full sample period (1989 through 2005) to estimate firm-specific target payout ratios and find similar results.

We perform additional tests to determine the sensitivity of the results to the sample composition. Because the dependent variables, $\triangle$ Payout, $\Delta$ Dividends, and $\Delta S h r R e p$, include a large proportion of zeros, we investigate the sensitivity of our results to omitting observations that do not pay dividends or make share repurchases. We report the results of estimating Equation (8) without observations with a value of zero for $\Delta$ ShrRep in Table 10 Column (3). The results are consistent with our hypotheses, and the magnitude of the coefficient on PostAct*Repatriate is similar to that reported in Table $8\left(\beta_{3}=0.00254 ; \mathrm{t}=2.26\right)$. To determine whether our results are driven by the inclusion of firms with small amounts of foreign activity, in Column (4) of Table 10 we report the results of estimating Equation (8) using only the 1,462 firms that report foreign segment sales. Once again, results are consistent with those reported in Table $8\left(\beta_{3}=0.00229 ; \mathrm{t}=3.26\right){ }^{35}$

\subsection{OTHER USES OF THE REPATRIATED FUNDS}

The results in Table 8 suggest that increases in repurchases account for only 20.87 percent of the $\$ 292$ billion that firms repatriate under the Act. To investigate other possible uses

\footnotetext{
${ }^{35}$ We also investigate whether our results are affected by changes in the sample over time by estimating Equation (8) for a balanced panel of firms with data available for each quarter from 1989 through 2005. Results are similar to those reported in Table 8 .
} 
of the repatriated funds, we examine the statement of cash flows of repatriating firms to identify how repatriated earnings are spent in 2005. If the entire \$291.6 billion represents cash abroad that is repatriated to the U.S. and then spent during 2005, we would expect to see a surge in the net cash outflow of repatriating firms resulting in lower levels of cash. However, untabulated data indicate that cash balances of repatriating firms increase between 2004 and 2005 (\$818.4 billion and $\$ 941.4$ billion, respectively). One explanation for this increase is that firms could have converted foreign assets to cash for repatriation, but have not yet invested the remitted cash. Another is that firms borrowed abroad to repatriate earnings but have not yet invested the cash. Finally, higher levels of cash could be indicative of an increase in cash flows from operations.

To further explore how firms use repatriated funds, we examine payments by repatriating firms for both allowed and disallowed uses of repatriated funds. Figure 3 illustrates cash inflows and outflows on the firms' statements of cash flows including payments for repurchases, dividends, acquisitions, investments, debt, property plant and equipment, currency translation adjustments, R\&D, and pension assets. Payments for acquisitions and R\&D, allowed uses of repatriated funds, decrease insignificantly during 2005, whereas payments for capital expenditures (allowed) and dividends (disallowed) increase during 2005, but by insignificant amounts. Debt issuances and currency translation adjustments significantly increase during 2005 but neither of these items represents significant uses of cash. Therefore, Figure 3 implies that, of all the possible uses of funds that we identify, only repurchases increase by a significant amount in 2005. Further, the results in Table 8 suggest that, of the total $\$ 80$ billion increase in repurchases from 2004 to 2005, 75 percent ( $\$ 60$ billion) is attributable to the Act. ${ }^{36}$

\footnotetext{
${ }^{36}$ Our findings are also consistent with repatriating firms continuing to hold their repatriated funds in reserve for spending in future periods. However, our review of the spending during 2006 does not provide evidence that investment spending has increased.
} 
However, the results in Figure 3 must be interpreted with caution. We can only observe net cash flows at the consolidated level. If, for example, a firm repatriates under the Act and intends to use the remitted funds towards domestic rather than foreign $R \& D$, the net $R \& D$ at the consolidated level would show no change. Note that share repurchases do not suffer from this limitation. To the extent that consolidated data suggest that repatriating firms use the funds to repurchase shares, repatriated earnings are not used for the activities listed by Congress and Treasury as approved uses.

\section{Summary and Conclusion}

On October 22, 2004 Congress passed the American Jobs Creation Act that provides a one-time 85 percent dividends received deduction on dividends received by U.S. multinational corporations from their foreign subsidiaries. The purpose of the Act is to encourage multinational firms to bring funds currently held in foreign subsidiaries back to the U.S. and use those funds to increase jobs and capital investment. However, our theory suggests that firms likely to repatriate under the Act are those with limited investment opportunities in both the U.S. and abroad. Therefore, under the assumptions of constant and exogenous tax rates, after-tax returns, and cost of capital, the optimal use of repatriated funds is to make shareholder distributions. Consistent with this prediction, we find that the likelihood that firms repatriate under the Act is decreasing in changes in return on assets and market to book ratios in the years preceding the Act, and increasing in free cash flows. Further, we find evidence that firms repatriating under the Act increase repurchases after the Act relative to non-repatriating firms but do not significantly increase dividend payments. Finally, we do not find evidence that spending on $R \& D$, acquisitions, or property plant and equipment significantly increase during the period 
subsequent to the Act. However, this result is subject to the limitation that we can only observe cash outflows for these purposes on a world-wide basis. 


\section{References}

Albring, S., A. Dzuranin, and L. Mills. 2005. Tax savings on repatriations of foreign earnings under the American Jobs Creation Act of 2004. Tax Notes 108 (August 8): 655-670

Alexander, R., and S. Scholz. 2008. Tax repatriation: Who buys when taxes go on sale? University of Kansas working paper.

Altshuler, R. and T Newlon. 1993. The effects of U.S. tax policy on the income repatriation patterns of U.S. multinational corporations. In Studies in International Taxation, edited by A. Giovannini, R. Hubbard, and J. Slerod. Chicago, IL: University of Chicago Press: 77-115.

Altshuler, R., T. Newlon and W. Randolph. 1995. Do repatriation taxes matter? Evidence from the tax returns of multinationals. In the Effects of Taxation on Multinational Corporations, edited by Martin Feldstein, James R. Hines, Jr., and R. Glenn Hubbard, 253-272. Chicago: University of Chicago Press.

Barclay, M., C. Smith, and R. Watts. 1995. The determinants of corporate leverage and dividend policies. Journal of Applied Corporate Finance 7:4, 4-19.

Bates, T. W. 2005. Asset sales, investment opportunities, and the use of proceeds. Journal of Finance 60:1, 105-135,

Blanchard, O. J., F. Lopez-de-Silanes, and A. Shleifer. 1994. What do firms do with cash windfalls? Journal of Financial Economics 36:3, 337-360.

Blessing, Peter H. 2004. Bringing it all back home: Earnings repatriations under the U.S. Jobs Act. Tax Notes International 36 (November 15, 2004), 625-639.

Clausing, Kimberly A. 2005. Tax holidays (and other escapes) in the American Jobs Creation Act. National Tax Journal 58:3, 331-346.

Collins, J., Hand, J., and D. Shackelford. 2001. Valuing Deferral: The effect of permanently reinvested foreign earnings on stock prices. In International Taxation and Multinational Activity, edited by J. Hines. Chicago, IL: University of Chicago Press, 143-166.

Congressional Record. 2004. Senator Breaux speaking on the Breaux-Feinstein amendment to the Jumpstart Our Business Strength Act. S4862 (May 5).

Congressional Record. 2004b. S4861-S4868 (May 5).

Core, John E., Wayne R. Guay, Scott A. Richardson and Rodrigo S. Verdi. 2006. Stock market anomalies: Corroborating evidence from repurchases and insider trading. Forthcoming in Review of Accounting Studies. 
Desai, Mihir A., C. Fritz Foley and James R. Hines. 2001. Repatriation taxes and dividend distortions. National Tax Journal 54:4, 829-851.

De Waegenaere, A., and R. Sansing. 2008. Taxation of international investment and accounting valuation. Forthcoming in Contemporary Accounting Research.

Dittmar, Amy K. 2000. Why do firms repurchase stock? Journal of Business 73:3, 331-355.

Fama, E. and K. French. 1997. Industry costs of equity. Journal of Financial Economics 43:2, 153-193.

Fama, E. and K. French. 2001. Disappearing dividends: Changing firm characteristics or lower propensity to pay? Journal of Financial Economics 60:1:, 3-43.

Foley, Fritz, Jay C. Hartzell, Sheridan Titman, and Garry Twite. 2007. Why do firms hold so much cash? A tax-based explanation. Forthcoming in the Journal of Financial Economics.

Grubert, H. 1998. Taxes and the division of foreign operating income among royalties, interest, dividends and retained earnings. Journal of Public Economics 68 (2): 269-290.

Grullon, G. and R. Michaely. 2002. Dividends, share repurchases and the substitution hypothesis. Journal of Finance 57, 1649-1684.

Grullon, G. and R. Michaely. 2004. The information content of share repurchase programs. Journal of Finance 59, 651-680.

Guay, Wayne and Jarrad Harford. 2000. The cash-flow permanence and information content of dividend increases versus repurchases. Journal of Financial Economics 57:3, 385-415.

Hartman, David. 1985. Tax policy and foreign direct investment. Journal of Public Economics 26, 107-121.

Heckman, J. 1979. Sample selection bias as a specification error. Econometrica 47, 153-161.

Hines, James R. 1994. Credit deferral as international investment incentives. Journal of Public Economics 55, 323-347.

Hines, James R. and R. Glenn Hubbard. 1990. Coming home to America: Dividend repatriations by U.S. multinationals. In Taxation in the Global Economy, edited by Assaf Razin and Joel Slemrod, Chicago: University of Chicago Press, 161-200.

Hribar, Paul, Nicole Thorne Jenkins and W. Bruce Johnson. 2005. Stock repurchases as an earnings management device. Journal of Accounting and Economics 41, 3-27. 
Jensen, Michael C. 1986. Agency costs of free cash flow, corporate finance and takeovers. The American Economic Review 76, 323-329.

Krull, Linda. 2004. Permanently reinvested foreign earnings, taxes, and earnings management. The Accounting Review 79:3, 745-767.

Lintner, J. 1956, Distribution of incomes of corporations among dividends, retained earnings and taxes, American Economic Review 46, 97-113.

Maddala, G. 1983. Limited dependent and qualitative variables in econometrics. New York: Cambridge University Press.

Oler, M., T. Shevlin, and R. Wilson. 2007. Examining investor expectations concerning tax savings on the repatriations of foreign earnings under the American Jobs Creation Act of 2004, Journal of the American Taxation Association 29:2, 25-55..

Pontiff, Jeffrey and Artemiza Woodgate. 2005. Shares outstanding and cross-sectional returns. Boston College working paper.

Poterba, J., and L. Summers. 1985. The economic effects of dividend taxation. In Recent Advances in Corporate Finance, edited by E. Altman and M. Subrahmanyam. Homewood, IL: Irwin.

Redmiles, Melissa. 2008. The one-time dividends received deduction. Statistics of Income Tax Stats http://www.irs.gov/taxstats/bustaxstats/article/0,id=180693,00.html.

Scholes, Myron S., Mark A. Wolfson, Merle Erickson, Edward L. Maydew and Terry Shevlin. 2005. Taxes and Business Strategy: A Planning Approach. $3^{\text {rd }}$ edition. Prentice Hall, Upper Saddle River, NJ 07458.

Skinner, D. 2008. The evolving relation between earnings, dividends, and stock repurchases. Journal of Financial Economics 87: 582-609.

Stoffregen, P., S. Lainoff., and E. Satkoski. 2005. Bringing it home: Summary and analysis of the repatriation provision of the American Jobs Creation Act. The Tax Executive JanuaryFebruary, 45-57.

Vermaelen, T. 1981. Common stock repurchases and market signaling: An empirical study. Journal of Financial Economics 9, 139-183. 
FIGURE 1

Net Quarterly Dividends from Foreign Subsidiaries

This figure graphs net quarterly dividends received by U.S. multinational corporations from foreign subsidiaries using the Federal Reserve Board Flow of Funds data. Amounts are the sum of net dividends received from foreign subsidiaries for each quarter from the first quarter of 1989 through the fourth quarter of 2005. Values on the y-axis are in \$ millions.

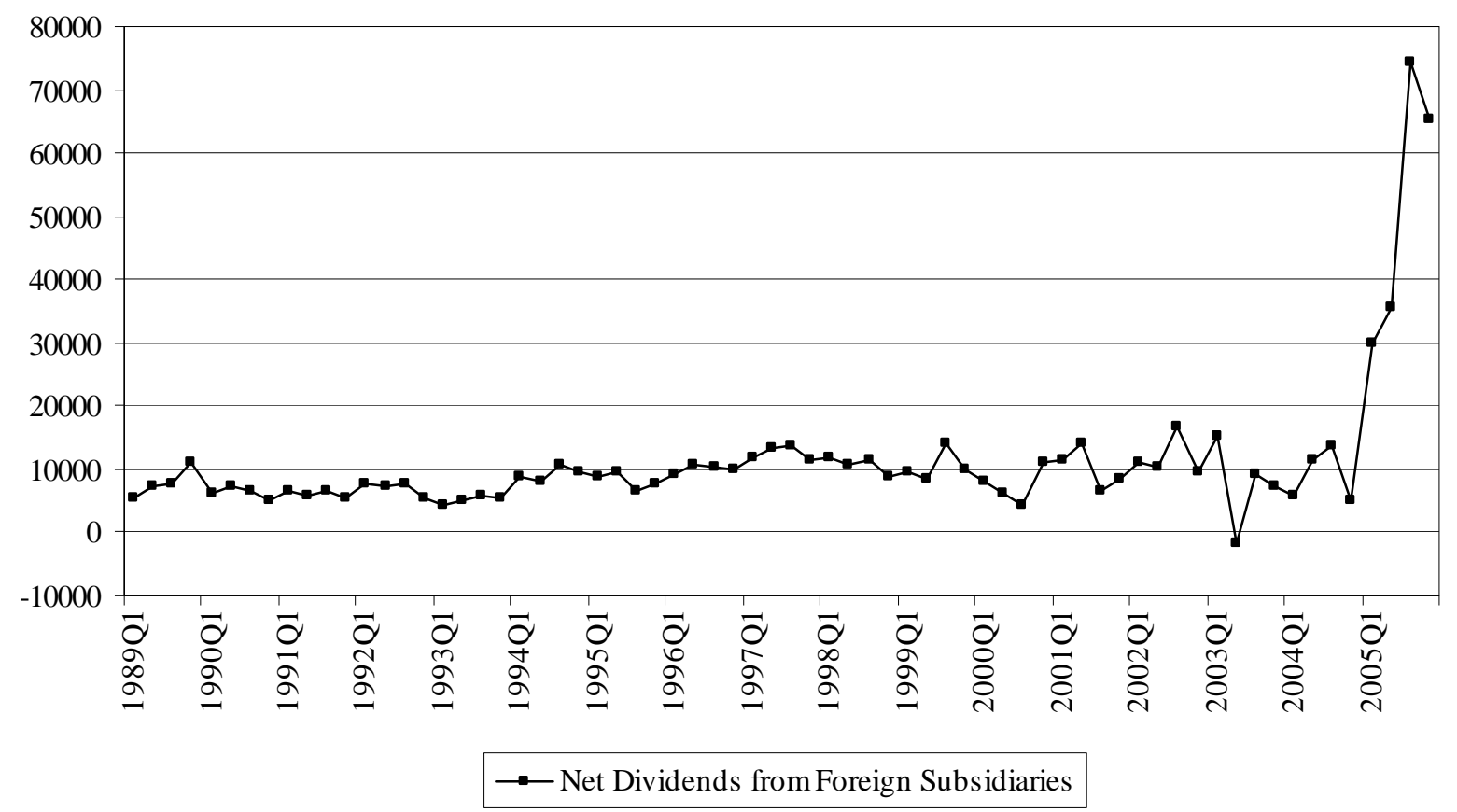


FIGURE 2

Total Quarterly Share Repurchases and Shareholder Dividends

This figure graphs total share repurchases and total shareholder dividends paid by sample firms from the first quarter of 1989 through the fourth quarter of 2005. The sample includes firms listed on Compustat, incorporated in the U.S. that have non missing foreign activity in at least one of the previous three years, excluding insurance companies and financial services firms and observations in the top 0.5 percent of the sample. Total Share Repurchases equals the sum of repurchases for sample firms for the quarter where repurchases equals the change in treasury stock (data226). If there is a net decrease in treasury stock, then repurchases equals zero. For those firms that do not use the treasury stock method, we estimate repurchases as repurchases of common and preferred stock from the Statement of Cash Flows less the decrease in preferred stock from the Compustat Industrial Quarterly files (data93 less the change in data51 and the change in data71). Total Shareholder Dividends equals total dividends paid by sample firms during the quarter where dividends equals dividends per share times the number of shares outstanding from the Compustat Industrial Quarterly files. Values on the y-axis are in \$ millions.

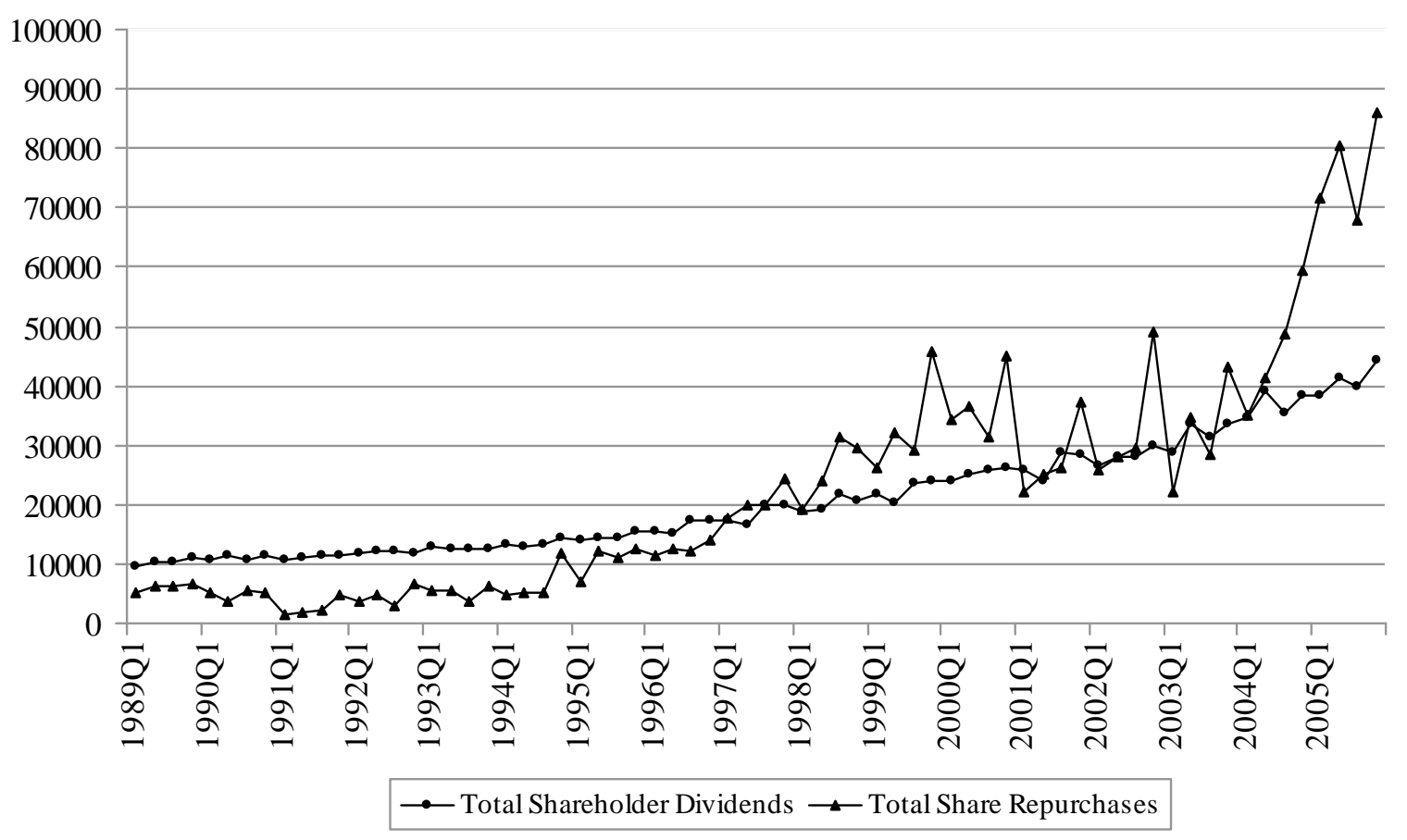




\section{FIGURE 3}

Changes in Cash Outflows for Repatriating Firms

Figure 3 reports changes in cash outflows for 357 firms that repatriate under the Act. Dividends are cash dividends as reported on the statement of cash flows (data127). Repurchases are purchases of common and preferred stock (data115). Acquisitions are as reported on the statement of cash flows (data129). Net Capex represents net capital expenditures defined as purchases of property, plant, and equipment less proceeds from the sale of property, plant, and equipment (data128 - data107). $R D$ is research development defined as R\&D plus advertising expenditures (data45 + data46). Net Chg in Pension represents the net change in net pension assets (data287 - data286 - (lagged data287 - lagged data286)). Net Investments represents purchases of marketable securities, investments in unconsolidated subsidiaries and other long-term investments less sales of these items (data113 - data109). Net ST Investments represents purchases of short-term marketable securities and other short-term investments less sales of these items (-data309). Misc Investments are net other cash inflows and outflows found in the investing section of the statement of cash flows (-data310). Net LTD is payments of long-term debt net of issuances (data114 -

data111). Net Current Debt is payments of short-term debt net of issuances (-data301). Stock Issuances are sales and issuances of common and preferred stock (-data108). Misc Financing is net other cash inflows and outflows found in the financing section of the statement of cash flows (-data312). FX Effects are the exchange rate effects on cash balances as reported on the statement of cash flows (-data314). Total Investment is the sum of Net Capex, Acquisitions, RD and Misc Investments. Amounts are scaled by world-wide assets (data6).

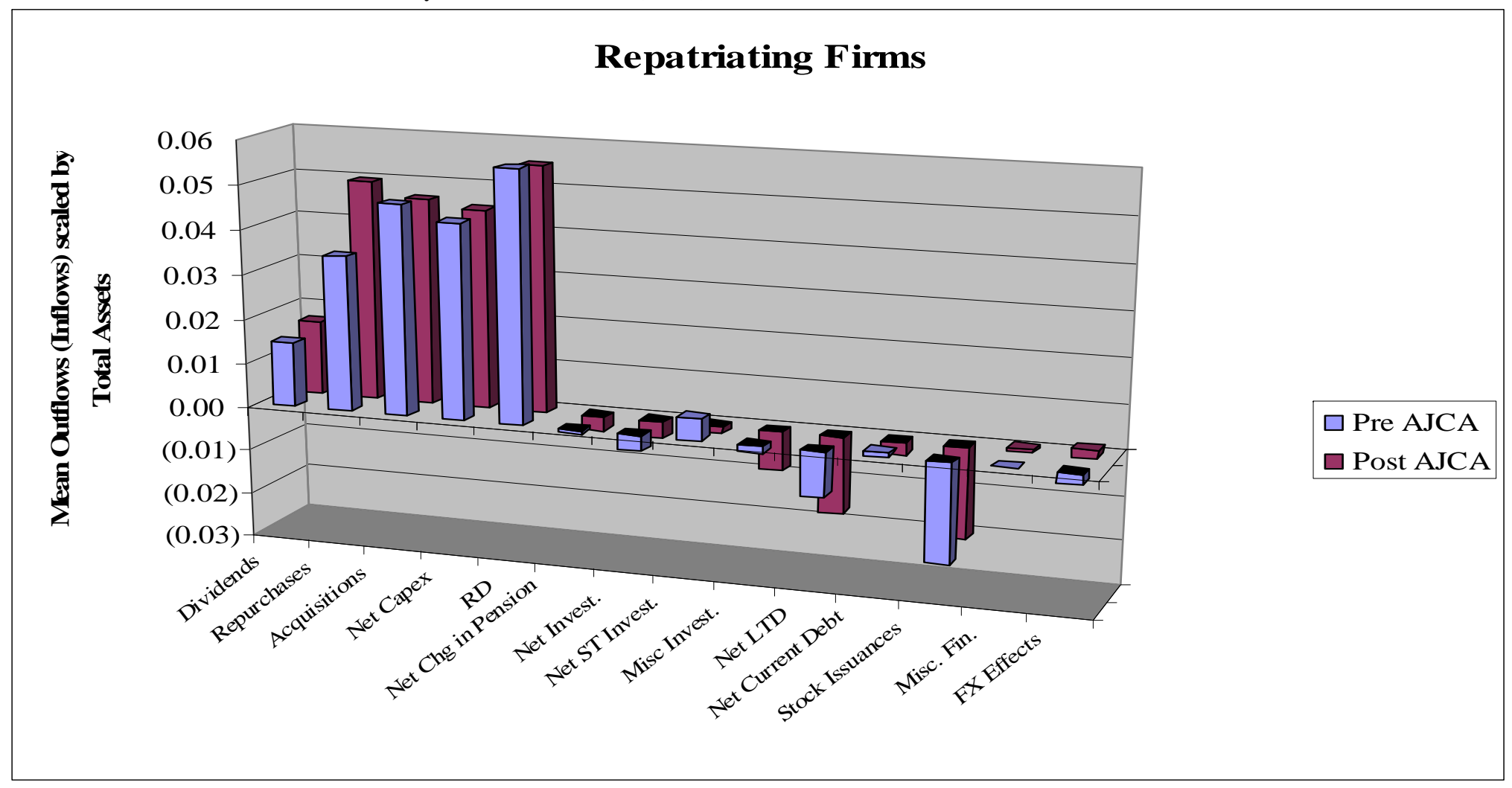


TABLE 1

Descriptive Statistics for the Lexis-Nexis Sample and the Compustat Sample

This table reports annual means and medians of descriptive data as of the end of 2004 for the samples of repatriating and non-repatriating firms. We include all firms with Compustat data available for the period 2001 to 2005, excluding firms with negative book values, firms incorporated outside the U.S, insurance companies, financial services firms, and firms with missing foreign activity in each of the last three years. Repatriating firms are those that state that they will repatriate under the Act. Non-repatriating firms those that either state that they will not repatriate under the Act or do not mention the tax holiday in their financial statements. Assets equals world-wide assets (data6). MVE is price per share (data199) times common shares outstanding in millions (data25). Debt is the ratio of long-term debt (data9) plus the debt included in current liabilities (data34) to worldwide assets (data6). Cash is cash and marketable securities (data1) scaled by world-wide assets (data6). MB is the ratio of the market value to book value ((data25*data199)/data60). $R O A$ is net income (data172) scaled by worldwide assets (data6). FPTI is the ratio of foreign pre-tax income (data273) to world-wide assets (data6). ETR is the total effective tax rate measured as total tax expense (data16) over pre-tax income (data170). USTR, the U.S. effective tax rate, is domestic tax expense (data63) over domestic pre-tax income (data272). FTR is the foreign effective tax rate calculated as foreign tax expense (data64) over foreign pre-tax income (data273). PRE is the amount of permanently reinvested foreign subsidiary earnings reported in the income tax footnote. Total Repatriation is the amount the firm reports that it has or plans to repatriate under the provisions of the Act in its 2004 or 2005 10-K. Dollar amounts are in \$ millions.

\begin{tabular}{lccccccc}
\cline { 1 - 3 } Variable & \multicolumn{3}{c}{ Repatriating Firms } & & \multicolumn{3}{c}{ Non-Repatriating Firms } \\
\cline { 8 - 9 } \cline { 7 - 8 } Assets & $\mathrm{N}$ & Mean & Median & & $\mathrm{N}$ & Mean & Median \\
MVE & 357 & $15,382.55$ & $2,486.74$ & & 2,339 & $2,449.38$ & 280.95 \\
Debt & 357 & $14,801.79$ & $3,395.84$ & & 2,339 & $2,085.55$ & 337.80 \\
Cash & 357 & 0.216 & 0.202 & & 2,339 & 0.197 & 0.141 \\
MB & 357 & 0.177 & 0.117 & & 2,339 & 0.228 & 0.131 \\
ROA & 357 & 3.538 & 2.811 & & 2,339 & 2.948 & 2.200 \\
FPTI & 357 & 0.070 & 0.066 & & 2,339 & 0.011 & 0.039 \\
ETR & 357 & 0.042 & 0.030 & & 2,339 & 0.006 & 0.000 \\
USTR & 357 & 0.294 & 0.302 & & 2,339 & 0.231 & 0.290 \\
FTR & 357 & 0.184 & 0.101 & & 2,339 & 0.052 & 0.000 \\
PRE & 357 & 0.220 & 0.207 & & 2,339 & 0.081 & 0.000 \\
Total & 280 & $1,136.78$ & 153.15 & & N/A & N/A & N/A \\
Repatriation & 350 & 833.14 & 152.50 & & N/A & N/A & N/A \\
\hline
\end{tabular}


TABLE 2

Sample Composition by Industry

This table provides the sample industry composition (Fama and Frech 1997) by repatriation status. Repatriating firms include firms that state that they will repatriate under the Act. Non-repatriating firms include firms that either state that they will not repatriate under the Act or do not mention the tax holiday in their financial statements. See Table 1 for additional sample selection criteria. Cash is total cash (data1) scaled by assets (data6). Rep/Cash is the amount the firm reports that it has or plans to repatriate scaled by total cash (data1).

\begin{tabular}{|c|c|c|c|c|c|c|c|}
\hline \multirow{2}{*}{$\begin{array}{l}\text { Fama French } \\
\text { Industries }\end{array}$} & \multirow[b]{2}{*}{$\mathbf{N}$} & \multicolumn{3}{|c|}{ Repatriating Firms } & \multicolumn{3}{|c|}{ Non-Repatriating Firms } \\
\hline & & $\%$ & Cash & Rep/Cash & $\mathbf{N}$ & $\%$ & Cash \\
\hline Agriculture & 0 & $\mathrm{~N} / \mathrm{A}$ & $\mathrm{N} / \mathrm{A}$ & $\mathrm{N} / \mathrm{A}$ & 10 & $0.43 \%$ & 0.19 \\
\hline Food & 10 & $2.80 \%$ & 0.08 & 1.7 & 34 & $1.45 \%$ & 0.11 \\
\hline Soda & 1 & $0.28 \%$ & 0.01 & 10.32 & 5 & $0.21 \%$ & 0.08 \\
\hline Beer & 4 & $1.12 \%$ & 0.12 & 2.36 & 7 & $0.30 \%$ & 0.15 \\
\hline Smoke & 2 & $0.56 \%$ & 0.11 & 0.54 & 1 & $0.04 \%$ & 0.12 \\
\hline Toys & 5 & $1.40 \%$ & 0.22 & 1.19 & 17 & $0.73 \%$ & 0.16 \\
\hline Fun & 1 & $0.28 \%$ & 0.04 & 0.19 & 35 & $1.50 \%$ & 0.15 \\
\hline Books & 1 & $0.28 \%$ & 0.12 & 0.31 & 26 & $1.11 \%$ & 0.15 \\
\hline Household & 12 & $3.36 \%$ & 0.09 & 2.08 & 29 & $1.24 \%$ & 0.15 \\
\hline Clothes & 10 & $2.80 \%$ & 0.21 & 0.73 & 37 & $1.58 \%$ & 0.14 \\
\hline Health & 9 & $2.52 \%$ & 0.14 & 0.57 & 119 & $5.09 \%$ & 0.24 \\
\hline Med Eq & 17 & $4.76 \%$ & 0.2 & 1.07 & 85 & $3.63 \%$ & 0.28 \\
\hline Drugs & 25 & $7.00 \%$ & 0.23 & 1.14 & 147 & $6.28 \%$ & 0.56 \\
\hline Chemicals & 20 & $5.60 \%$ & 0.05 & 4.34 & 30 & $1.28 \%$ & 0.15 \\
\hline Rubber & 5 & $1.40 \%$ & 0.07 & 1.44 & 15 & $0.64 \%$ & 0.06 \\
\hline Textiles & 3 & $0.84 \%$ & 0.05 & 1.09 & 9 & $0.38 \%$ & 0.15 \\
\hline Bldg Mat & 10 & $2.80 \%$ & 0.07 & 0.63 & 43 & $1.84 \%$ & 0.16 \\
\hline Construction & 1 & $0.28 \%$ & 0.03 & 0.29 & 38 & $1.62 \%$ & 0.14 \\
\hline Steel & 7 & $1.96 \%$ & 0.07 & 2.48 & 30 & $1.28 \%$ & 0.06 \\
\hline Fab Pr & 0 & N/A & N/A & N/A & 7 & $0.30 \%$ & 0.04 \\
\hline Machinery & 19 & $5.32 \%$ & 0.11 & 1.75 & 81 & $3.46 \%$ & 0.18 \\
\hline Electrical Eq & 8 & $2.24 \%$ & 0.14 & 0.99 & 41 & $1.75 \%$ & 0.20 \\
\hline Misc & 4 & $1.12 \%$ & 0.04 & 0.7 & 14 & $0.60 \%$ & 0.36 \\
\hline Autos & 10 & $2.80 \%$ & 0.1 & 1.49 & 26 & $1.11 \%$ & 0.13 \\
\hline Aero & 7 & $1.96 \%$ & 0.07 & 0.68 & 10 & $0.43 \%$ & 0.06 \\
\hline Ships & 0 & N/A & N/A & N/A & 7 & $0.30 \%$ & 0.14 \\
\hline Defense & 0 & N/A & N/A & N/A & 5 & $0.21 \%$ & 0.10 \\
\hline Gold & 0 & N/A & N/A & N/A & 4 & $0.17 \%$ & 0.15 \\
\hline Mines & 1 & $0.28 \%$ & 0.06 & 0.94 & 6 & $0.26 \%$ & 0.16 \\
\hline Coal & 0 & N/A & N/A & N/A & 2 & $0.09 \%$ & 0.08 \\
\hline Energy & 16 & $4.48 \%$ & 0.09 & 4.88 & 80 & $3.42 \%$ & 0.12 \\
\hline Utilities & 1 & $0.28 \%$ & 0.02 & 1.12 & 33 & $1.41 \%$ & 0.04 \\
\hline Telecom & 2 & $0.56 \%$ & 0.03 & 0.24 & 65 & $2.78 \%$ & 0.17 \\
\hline Personal Svcs & 1 & $0.28 \%$ & 0.26 & 0.13 & 15 & $0.64 \%$ & 0.07 \\
\hline Business Svcs & 31 & $8.68 \%$ & 0.35 & 0.56 & 267 & $11.42 \%$ & 0.34 \\
\hline Computers & 18 & $5.04 \%$ & 0.36 & 0.41 & 102 & $4.36 \%$ & 0.40 \\
\hline Chips & 34 & $9.52 \%$ & 0.32 & 0.48 & 176 & $7.52 \%$ & 0.36 \\
\hline Lab Eq & 13 & $3.64 \%$ & 0.18 & 1.38 & 75 & $3.21 \%$ & 0.30 \\
\hline Paper & 10 & $2.80 \%$ & 0.07 & 9.62 & 24 & $1.03 \%$ & 0.08 \\
\hline Boxes & 4 & $1.12 \%$ & 0.04 & 1.27 & 4 & $0.17 \%$ & 0.04 \\
\hline Transport & 2 & $0.56 \%$ & 0.28 & 0.57 & 67 & $2.86 \%$ & 0.11 \\
\hline Wholesale & 7 & $1.96 \%$ & 0.06 & 0.43 & 98 & $4.19 \%$ & 0.11 \\
\hline Retail & 17 & $4.76 \%$ & 0.19 & 0.53 & 147 & $6.28 \%$ & 0.13 \\
\hline Meals & 3 & $0.84 \%$ & 0.04 & 2.48 & 54 & $2.31 \%$ & 0.10 \\
\hline Real Estate & 0 & N/A & N/A & N/A & 20 & $0.86 \%$ & 0.13 \\
\hline Fin & 6 & $1.68 \%$ & 0.27 & 2.68 & 192 & $8.21 \%$ & 0.14 \\
\hline Total & 357 & & 0.18 & 1.66 & 2339 & & 0.23 \\
\hline
\end{tabular}




\section{Table 3}

\section{Incentives to Repatriate}

Total Repatriation/Assets is the ratio of the amount the firm reports that it has repatriated or plans to repatriate in \$ millions to world-wide assets (data6). Each of the change variables $(\Delta)$ is the mean of the change in the firm's measure over the three-year period 2002 to 2004 . $\triangle F P T I$ equals the change in foreign pre-tax income (data273) scaled by world-wide assets (data6); $\triangle R O A$ is the change in net income (data172) scaled by world-wide assets (data6); $\triangle M B$ equals the change in the firm's market to book value ratio ((data25*data199)/data60); $\triangle R D$ equals the change in the ratio of R\&D to world-wide assets; $\Delta C a p E x$ equals the change in capital expenditures (data128) divided by world-wide assets; FCF equals average operating cash flows (data308) divided by world-wide assets for the period 2002 to 2004; RateDum equals one if the U.S tax rate of 0.35 exceeds the average foreign tax rate (data64/data273) from 2002 through 2004, and zero otherwise; and USTR equals the average U.S. tax rate (data63/data272) from 2002 through 2004. \%FAssets is the ratio of FAssets (foreign assets estimated as described in Oler et al. (2007)) to world-wide assets (data6). $\triangle F R O A$ is the change in foreign ROA where FROA is estimated using the process described in Oler et al (2007). $\triangle U S R O A$ is change in domestic ROA where USROA is ROA less FROA. Repatriating firms include firms that state that they will repatriate under the Act. Nonrepatriating firms include firms that either state that they will not repatriate under the Act or do not mention the tax holiday in their financial statements. The sample in Panel A includes the 2,696 firms described in Table 1. The sample in Panel B is only firms with non-missing foreign segment sales information. All continuous variables are winsorized at the top and bottom 0.5 percent. $* * *, * *, *$ indicates significantly different from the repatriating sample at the 1 percent, 5 percent and 10 percent level, respectively.

Panel A: Full Sample

\begin{tabular}{|c|c|c|c|c|c|c|}
\hline & & epatriating & & & Repatriating $\mathrm{F}$ & \\
\hline & $\mathrm{N}$ & Mean & Median & $\mathrm{N}$ & Mean & Median \\
\hline Total Repatriation/Assets & 350 & 0.116 & 0.076 & 2,339 & $\mathrm{~N} / \mathrm{A}^{* * *}$ & N/A \\
\hline$\Delta \mathrm{FPTI}$ & 357 & 0.001 & 0.000 & 2,339 & $0.011^{* *}$ & 0.000 \\
\hline$\triangle \mathrm{ROA}$ & 357 & 0.009 & 0.006 & 2,339 & $0.017^{* *}$ & 0.004 \\
\hline$\Delta \mathrm{MB}$ & 357 & -0.218 & -0.011 & 2,339 & $0.077^{* * *}$ & 0.101 \\
\hline$\Delta \mathrm{RD}$ & 357 & -0.001 & 0.000 & 2,339 & -0.000 & 0.000 \\
\hline$\Delta$ CapEx & 357 & -0.004 & -0.002 & 2,339 & -0.003 & 0.000 \\
\hline FCF & 357 & 0.120 & 0.115 & 2,339 & $0.054^{* * *}$ & 0.072 \\
\hline RateDum & 357 & 0.642 & 1.00 & 2,339 & $0.217^{* * *}$ & 0 \\
\hline USTR & 357 & 0.165 & 0.069 & 2,339 & $0.051^{* * *}$ & 0 \\
\hline FAssets & 357 & $4,885.070$ & 725.852 & 2,339 & $415.270^{* * *}$ & 0 \\
\hline \%FAssets & 357 & 0.438 & 0.398 & 2,339 & $0.202^{* * *}$ & 0 \\
\hline
\end{tabular}


Panel B: Firms with Non-missing Foreign Segment Sales

\begin{tabular}{|c|c|c|c|c|c|c|}
\hline & \multicolumn{3}{|c|}{ Repatriating Firms } & \multicolumn{3}{|c|}{ Non-Repatriating Firms } \\
\hline & $\mathrm{N}$ & Mean & Median & $\mathrm{N}$ & Mean & Median \\
\hline Total Repatriation/Assets & 330 & 0.124 & 0.082 & 1,126 & N/A & N/A \\
\hline$\Delta$ FPTI & 336 & -0.031 & 0.015 & 1,126 & $0.001 *$ & 0.000 \\
\hline$\triangle \mathrm{ROA}$ & 336 & -0.002 & -0.001 & 1,126 & $0.010^{* *}$ & -0.000 \\
\hline$\triangle \mathrm{FROA}$ & 331 & 0.014 & 0.005 & 1,041 & 0.009 & 0.000 \\
\hline$\triangle \mathrm{USROA}$ & 331 & -0.002 & -0.001 & 1,041 & $0.018^{* * *}$ & 0.005 \\
\hline$\Delta \mathrm{MB}$ & 336 & -0.386 & -0.014 & 1,126 & $-0.148 * * *$ & 0.042 \\
\hline$\Delta \mathrm{RD}$ & 336 & -0.001 & 0.000 & 1,126 & -0.001 & 0.000 \\
\hline$\Delta$ CapEx & 336 & -0.004 & -0.003 & 1,126 & -0.005 & -0.003 \\
\hline FCF & 336 & 0.120 & 0.115 & 1,126 & $0.055^{* * *}$ & 0.067 \\
\hline RateDum & 336 & 0.628 & 1.000 & 1,126 & $0.384^{* * *}$ & 0.000 \\
\hline USTR & 336 & 0.170 & 0.164 & 1,126 & $0.087^{* * *}$ & 0.001 \\
\hline FAssets & 336 & 4858.52 & 874.25 & 1,126 & $851.55^{* * *}$ & 97.62 \\
\hline \%FAssets & 336 & 0.480 & 0.438 & 1,126 & 0.462 & 0.376 \\
\hline
\end{tabular}


TABLE 4

Characteristics of Repatriating Firms

Column (1) reports the results of estimating a logit model where the dependent variable, Repatriate, is equal to one if the firm states that it will repatriate under the Act, and zero otherwise. Columns (2) and (3) report the results of estimating a tobit model where the dependent variables are Total Repatriation divided by world-wide assets or lagged PRE. Total Repatriation equals the amount the firm states that it repatriated or plans to repatriate under the Act; PRE equals the amount the firm discloses as permanently reinvested earnings in the income tax footnote. Each of the change variables $(\Delta)$ is the mean of the change in the firm's measure over the three-year period 2002 to 2004. $\triangle F P T I$ equals the change in foreign pre-tax income (data273) scaled by world-wide assets (data6); $\triangle R O A$ is the change in net income (data172) scaled by world-wide assets (data6); $\triangle M B$ equals the change in the firm's market to book value ratio ((data25*data199)/data60); $\triangle R D$ equals the change in the ratio of R\&D to world-wide assets; $\triangle C a p E x$ equals the change in capital expenditures (data128) divided by world-wide assets; FCF equals average operating cash flows (data308) divided by world-wide assets for the period 2002 to 2004; RateDum equals one if the U.S tax rate of 0.35 exceeds the average foreign tax rate (data64/data273) from 2002 through 2004, and zero otherwise; and USTR equals the average U.S. tax rate (data63/data272) from 2002 through 2004. \%FAssets is the ratio of FAssets (foreign assets estimated as described in Oler et al. (2007)) to worldwide assets (data6). $\triangle F R O A$ is the change in foreign ROA where FROA is estimated using the process described in Oler et al. (2007). $\triangle U S R O A$ is change in domestic ROA where USROA is ROA less FROA. The sample in Panel A includes the 2,696 firms described in Table 1. The sample in Panel B is only firms with non-missing foreign segment sales information. All continuous variables are winsorized at the top and bottom 0.5 percent.

Panel A: Full Sample

\begin{tabular}{|c|c|c|c|c|c|c|c|}
\hline \multirow[b]{2}{*}{ Variable } & \multirow[b]{2}{*}{ Predicted } & \multicolumn{2}{|c|}{$\begin{array}{c}\text { (1) } \\
\text { Repatriate }\end{array}$} & \multicolumn{2}{|c|}{$\begin{array}{c}\text { (2) } \\
\text { Total Repatriation/Assets }\end{array}$} & \multicolumn{2}{|c|}{$\begin{array}{c}\text { (3) } \\
\text { Total Repatriation/PRE }\end{array}$} \\
\hline & & Coefficient & t-statistic & Coefficient & t-statistic & Coefficient & t-statistic \\
\hline Intercept & & -3.96 & -24.45 & -0.45 & -18.66 & -5.83 & -16.63 \\
\hline$\Delta \mathrm{FPTI}$ & - & -0.42 & -1.96 & -0.04 & -1.84 & -0.30 & -0.96 \\
\hline$\triangle \mathrm{ROA}$ & - & -3.26 & -1.80 & -0.42 & -2.11 & -4.19 & -1.55 \\
\hline$\Delta \mathrm{MB}$ & - & -0.09 & -1.69 & -0.01 & -2.19 & -0.15 & -1.95 \\
\hline$\Delta \mathrm{RD}$ & - & 2.56 & 0.34 & 0.28 & 0.34 & -1.76 & -0.16 \\
\hline$\Delta$ CapEx & - & 0.79 & 0.17 & -0.04 & -0.09 & 4.28 & 0.61 \\
\hline FCF & + & 7.15 & 8.68 & 0.83 & 9.30 & 8.18 & 6.52 \\
\hline RateDum & + & 1.92 & 10.29 & 0.21 & 10.47 & 2.41 & 8.37 \\
\hline USTR & + & 2.19 & 4.52 & 0.21 & 4.15 & 2.86 & 4.02 \\
\hline \%FAssets & + & 1.26 & 6.10 & 0.15 & 6.77 & 1.73 & 5.80 \\
\hline Scale & & & & 0.19 & & 2.53 & \\
\hline Log Likelihood & & -793.77 & & -373.49 & & -1042.94 & \\
\hline $\mathrm{N}$ & & 2,696 & $\operatorname{Rep}=357$ & 2,689 & $\operatorname{Rep}=350$ & 2,624 & $\operatorname{Rep}=285$ \\
\hline
\end{tabular}


Panel B: Firms with Non-missing Foreign Segment Sales

\begin{tabular}{|c|c|c|c|c|c|c|c|}
\hline \multirow[b]{2}{*}{ Variable } & \multirow[b]{2}{*}{ Predicted } & \multicolumn{2}{|c|}{$\begin{array}{c}\text { (1) } \\
\text { Repatriate }\end{array}$} & \multicolumn{2}{|c|}{$\begin{array}{c}\text { (2) } \\
\text { Total Repatriation/Assets }\end{array}$} & \multicolumn{2}{|c|}{$\begin{array}{c}\text { (3) } \\
\text { Repatriate }\end{array}$} \\
\hline & & Coefficient & t-statistic & Coefficient & t-statistic & Coefficient & t-statistic \\
\hline Intercept & & -2.85 & -15.12 & -0.35 & -14.53 & -2.70 & -14.16 \\
\hline$\Delta \mathrm{FPTI}$ & - & -0.40 & -1.89 & -0.04 & -1.78 & & \\
\hline$\triangle \mathrm{ROA}$ & - & -3.70 & -1.92 & -0.50 & -2.29 & & \\
\hline$\triangle \mathrm{USROA}$ & - & & & & & -2.42 & -1.91 \\
\hline$\triangle \mathrm{FROA}$ & - & & & & & -2.44 & -1.67 \\
\hline$\Delta \mathrm{MB}$ & - & -0.08 & -1.63 & -0.01 & -2.24 & -0.08 & -1.45 \\
\hline$\Delta \mathrm{RD}$ & - & 2.13 & 0.28 & 0.19 & 0.22 & 3.23 & 0.43 \\
\hline$\Delta$ CapEx & - & 2.30 & 0.45 & 0.03 & 0.05 & 1.33 & 0.25 \\
\hline FCF & + & 7.68 & 8.30 & 0.96 & 9.27 & 7.64 & 8.07 \\
\hline RateDum & + & 1.32 & 6.91 & 0.16 & 7.85 & 1.31 & 6.71 \\
\hline USTR & + & 1.55 & 3.18 & 0.15 & 2.78 & 1.46 & 2.97 \\
\hline \%FAssets & + & 0.11 & 0.49 & 0.03 & 1.32 & 0.07 & 0.33 \\
\hline Scale & & & & 0.19 & & & \\
\hline Log Likelihood & & -672.25 & & -292.85 & & -652.88 & \\
\hline $\mathrm{N}$ & & 1,462 & $\operatorname{Rep}=336$ & 1,456 & $\operatorname{Rep}=330$ & 1,372 & $\operatorname{Rep}=331$ \\
\hline
\end{tabular}




\section{TABLE 5}

\section{Total Repurchases for Partitions Based on Repatriation Plans}

This table reports mean repurchases as a percent of assets and total repurchases by quarter for repatriating and nonrepatriating firms. Repatriating firms are those that state that they will repatriate under the Act in fiscal year 2004 or 2005. Non-repatriating firms are those that state that they will not repatriate under the Act or do not mention the tax holiday. ShrRep is repurchases as a percent of assets measured as the change in treasury stock (data226) scaled by world-wide assets (data44) then multiplied by 100. If there is a net decrease in treasury stock, then repurchases equals zero. For those firms that do not use the treasury stock method, we estimate share repurchases as repurchases of common and preferred stock from the statement of cash flows (data93) less decreases in preferred stock (change in data55 and data71). Total Repurchases are the unscaled repurchases reported in \$ millions. We eliminate observations in the top 0.5 percent of ShrRep.

\begin{tabular}{|c|c|c|c|c|c|c|}
\hline \multirow[b]{2}{*}{ Period } & \multicolumn{3}{|c|}{ Repatriating Firms } & \multicolumn{3}{|c|}{ Non-Repatriating Firms } \\
\hline & $\mathrm{N}$ & $\begin{array}{c}\text { ShrRep } \\
\text { (Mean in \%) }\end{array}$ & $\begin{array}{c}\text { Total } \\
\text { Repurchases }\end{array}$ & $\mathrm{N}$ & $\begin{array}{c}\text { ShrRep } \\
\text { (Mean in \%) }\end{array}$ & $\begin{array}{c}\text { Total } \\
\text { Repurchases }\end{array}$ \\
\hline 2003: Q1 & 357 & 0.64 & $12,782.7$ & 2,335 & 0.30 & $9,631.2$ \\
\hline 2003: Q2 & 357 & 0.48 & $16,456.4$ & 2,337 & 0.23 & $8,701.7$ \\
\hline 2003: Q3 & 357 & 0.56 & $17,931.6$ & 2,335 & 0.20 & $11,571.7$ \\
\hline 2003: Q4 & 357 & 0.60 & $25,064.4$ & 2,337 & 0.25 & $15,232.8$ \\
\hline $\begin{array}{l}2003 \\
\text { Total }\end{array}$ & & 2.28 & $72,235.1$ & & 0.97 & $45,137.4$ \\
\hline 2004: Q1 & 356 & 0.65 & $22,631.3$ & 2,337 & 0.30 & $14,727.8$ \\
\hline 2004: Q2 & 357 & 0.69 & $21,509.2$ & 2,336 & 0.32 & $19,880.2$ \\
\hline 2004: Q3 & 357 & 0.89 & $28,619.1$ & 2,337 & 0.38 & $20,299.1$ \\
\hline 2004: Q4 & 357 & 0.72 & $28,041.9$ & 2,338 & 0.36 & 23,532.6 \\
\hline $\begin{array}{l}2004 \\
\text { Total }\end{array}$ & & 2.96 & $100,801.5$ & & 1.35 & $78,439.7$ \\
\hline 2005: Q1 & 356 & 0.92 & $33,450.8$ & 2,338 & 0.35 & $23,563.5$ \\
\hline 2005: Q2 & 357 & 1.07 & $42,086.8$ & 2,336 & 0.48 & $27,089.6$ \\
\hline 2005: Q3 & 356 & 1.18 & $40,289.6$ & 2,329 & 0.42 & $27,639.3$ \\
\hline 2005: Q4 & 357 & 1.15 & $50,579.9$ & 2,326 & 0.50 & $33,375.0$ \\
\hline $\begin{array}{l}2005 \\
\text { Total }\end{array}$ & & 4.32 & $166,407.1$ & & 1.75 & $111,667.4$ \\
\hline
\end{tabular}




\section{TABLE 6}

\section{Total Dividend Payments for Partitions Based on Repatriation Plans}

This table reports mean repurchases as a percent of assets and total repurchases by quarter for repatriating and nonrepatriating firms. Repatriating firms are those that report in their financial statements that they will repatriate under the Act in fiscal year 2004 or 2005. Non-repatriating firms are those that state that they will not repatriate under the Act or do not mention the tax holiday. Dividends equals dividends as a percent of assets calculated as quarterly dividends per share times total shares outstanding (data16*data61), divided by world-wide assets (data44) then multiplied by 100. Total Dividends is dividends per share times total shares outstanding (data16*data61), in \$ millions. We eliminate observations in the top 0.5 percent of Dividends.

\begin{tabular}{|c|c|c|c|c|c|c|}
\hline \multirow[b]{2}{*}{ Period } & \multicolumn{3}{|c|}{ Repatriating Firms } & \multicolumn{3}{|c|}{ Non-Repatriating Firms } \\
\hline & $\mathrm{N}$ & $\begin{array}{c}\text { Dividends } \\
\text { (Mean in \%) }\end{array}$ & $\begin{array}{c}\text { Total } \\
\text { Dividends }\end{array}$ & $\mathrm{N}$ & $\begin{array}{c}\text { Dividends } \\
\text { (Mean in \%) }\end{array}$ & $\begin{array}{c}\text { Total } \\
\text { Dividends }\end{array}$ \\
\hline 2003: Q1 & 357 & 0.27 & $16,495.7$ & 2,333 & 0.24 & $11,545.7$ \\
\hline 2003: Q2 & 357 & 0.28 & $16,792.3$ & 2,334 & 0.36 & $12,803.6$ \\
\hline 2003: Q3 & 357 & 0.37 & $16,862.7$ & 2,334 & 0.48 & $13,741.1$ \\
\hline 2003: Q4 & 357 & 0.37 & 21,302.6 & 2,338 & 0.44 & $14,735.4$ \\
\hline $\begin{array}{l}2003 \\
\text { Total }\end{array}$ & & 1.29 & $71,453.3$ & & 1.51 & $52,825.8$ \\
\hline 2004: Q1 & 357 & 0.30 & $17,655.5$ & 2,337 & 0.36 & $14,479.2$ \\
\hline 2004: Q2 & 357 & 0.45 & $18,571.4$ & 2,336 & 0.43 & $14,992.0$ \\
\hline 2004: Q3 & 357 & 0.34 & $19,782.7$ & 2,335 & 0.39 & $16,527.0$ \\
\hline 2004: Q4 & 357 & 0.52 & $54,998.7$ & 2,339 & 0.45 & $16,675.3$ \\
\hline $\begin{array}{l}2004 \\
\text { Total }\end{array}$ & & 1.61 & $111,008.3$ & & 1.63 & $62,673.6$ \\
\hline 2005: Q1 & 357 & 0.45 & $21,880.9$ & 2,337 & 0.44 & $16,159.8$ \\
\hline 2005: Q2 & 356 & 0.34 & $21,408.6$ & 2,336 & 0.52 & $17,980.2$ \\
\hline 2005: Q3 & 356 & 0.33 & $21,069.4$ & 2,328 & 0.48 & $17,869.7$ \\
\hline 2005: Q4 & 357 & 0.46 & $25,209.2$ & 2,326 & 0.66 & $19,598.7$ \\
\hline $\begin{array}{l}2005 \\
\text { Total }\end{array}$ & & 1.57 & 89,568.1 & & 2.11 & $71,608.4$ \\
\hline
\end{tabular}


TABLE 7

Sample Descriptive Statistics

The sample includes firm-quarters from the first quarter of 1989 to the fourth quarter of 2005 with data available to calculate all regression variables, excluding firms incorporated outside the U.S., financial services firms, insurance companies, firms with no foreign activity in the previous three years, and firms with negative book values. $\Delta$ Payout is the sum of $\Delta$ ShrRep and $\Delta$ Dividends. $\Delta$ ShrRep is the quarterly change in treasury stock (data226) scaled by world-wide assets (data44). If there is a net decrease in treasury stock, then repurchases equals zero. For those firms that do not use the treasury stock method, we estimate share repurchases as repurchases of common and preferred stock from the statement of cash flows (data93) less decreases in preferred stock (change in data55 and data71). Dividends is the change from quarter t-4 to quarter $\mathrm{t}$ in dividends per share times total shares outstanding (data16 * data61)) scaled by world-wide assets (data44). MaxRep is the amount the firm reports that it has repatriated or plans to repatriate divided by world-wide assets. PostAct equals one for the four quarters of 2005, zero otherwise. Repatriate equals one if the firm states that it will repatriated under to the Act. Size is the log of the market value of equity. Market value of equity equals price (data14) times common shares outstanding (data61). $\Delta C a p E x$ is the change in the ratio of capital expenditures (data90) to world-wide assets (data44) from the beginning of quarter t- 4 to the beginning of quarter t. $\Delta R O A$ is the change in the ratio of annualized net income (data69*4) to world-wide assets (data44) from quarter t-1 to quarter t. $R O A$ is the ratio of annualized net income (data69*4) to world-wide assets (data44). Debt is the ratio of long-term debt (data51) plus the debt included in current liabilities (data45) to world-wide assets (data44). DivYld is dividends per share (data16) scaled by price (data14). $\Delta$ Cash is the change in the ratio of cash and cash equivalents (data36) to world-wide assets (data44) from the beginning of quarter t- 4 to the beginning of quarter $t$. $\Delta$ Penalty equals the change in the dividend tax penalty from quarter t-4 to quarter t and the dividend tax penalty equals the dividend tax rate minus the capital gain tax rate divided by one minus the capital gain tax rate.

\begin{tabular}{|c|c|c|c|c|c|c|c|c|}
\hline & \multicolumn{2}{|c|}{ QTR1 } & \multicolumn{2}{|c|}{ QTR2 } & \multicolumn{2}{|c|}{ QTR3 } & \multicolumn{2}{|c|}{ QTR4 } \\
\hline & Mean & Median & Mean & Median & Mean & Median & Mean & Median \\
\hline $\mathrm{N}$ & 28,171 & 28,171 & 28,921 & 28,921 & 29,192 & 29,192 & 29,280 & 29,280 \\
\hline$\Delta$ Payout & 0.00027 & 0.00000 & 0.00039 & 0.00000 & 0.00032 & 0.00000 & 0.00036 & 0.00000 \\
\hline$\Delta$ ShrRep & 0.00027 & 0.00000 & 0.00035 & 0.00000 & 0.00029 & 0.00000 & 0.00037 & 0.00000 \\
\hline$\Delta$ Dividends & 0.00001 & 0.00000 & 0.00004 & 0.00000 & 0.00002 & 0.00000 & 0.00002 & 0.00000 \\
\hline MaxRep & 0.04296 & 0.00000 & 0.04454 & 0.00000 & 0.04331 & 0.00000 & 0.04079 & 0.00000 \\
\hline PostAct & 0.09517 & 0.00000 & 0.09267 & 0.00000 & 0.09201 & 0.00000 & 0.09177 & 0.00000 \\
\hline Repatriate & 0.15811 & 0.00000 & 0.15992 & 0.00000 & 0.15905 & 0.00000 & 0.15881 & 0.00000 \\
\hline Size & 5.65191 & 5.60495 & 5.65372 & 5.59172 & 5.68094 & 5.63616 & 5.66595 & 5.61139 \\
\hline$\Delta$ CapEx & -0.00083 & 0.00000 & -0.00078 & 0.00000 & -0.00077 & 0.00000 & -0.00071 & 0.00000 \\
\hline$\triangle \mathrm{ROA}$ & 0.00683 & -0.00328 & 0.01293 & 0.00642 & -0.00196 & 0.00014 & -0.01368 & -0.00070 \\
\hline ROA & 0.01145 & 0.03843 & 0.02407 & 0.04791 & 0.02110 & 0.04698 & 0.00695 & 0.04629 \\
\hline Debt & 0.21363 & 0.18376 & 0.21807 & 0.18988 & 0.21782 & 0.19001 & 0.21733 & 0.18958 \\
\hline DivYld & 0.00287 & 0.00000 & 0.00278 & 0.00000 & 0.00280 & 0.00000 & 0.00271 & 0.00000 \\
\hline$\Delta$ Cash & -0.00095 & 0.00009 & -0.00034 & 0.00005 & -0.00071 & 0.00004 & -0.00076 & 0.00000 \\
\hline$\Delta$ Penalty & -0.01522 & 0.00000 & -0.01354 & 0.00000 & -0.01329 & 0.00000 & -0.01333 & 0.00000 \\
\hline
\end{tabular}


TABLE 8

Regression Analysis of Changes in Total Payout, Repurchases, and Dividends around the Act

The sample includes firm-quarters from the first quarter of 1989 to the fourth quarter of 2005 with data available to calculate all regression variables, excluding firms incorporated outside the U.S., financial services firms, insurance companies, firms with no foreign activity in the previous three years, and firms with negative book values. $\Delta$ Payout is the sum of $\Delta$ ShrRep and $\Delta$ Dividends. $\Delta$ ShrRep is the change from quarter t-4 to quarter $\mathrm{t}$ in repurchases measured as the change in treasury stock (data226) scaled by world-wide assets (data44). If there is a net decrease in treasury stock, then repurchases equals zero. For those firms that do not use the treasury stock method, we estimate share repurchases as repurchases of common and preferred stock from the statement of cash flows (data93) less decreases in preferred stock (change in data55 and data71). $\Delta$ Dividends is the change from quarter $\mathrm{t}-4$ to quarter $\mathrm{t}$ in dividends per share times total shares outstanding (data16* data61)) scaled by world-wide assets (data44). PostAct equals one for the four quarters of 2005, zero otherwise. Repatriate equals 1 if the firm states that it will repatriate under to the Act. MaxRep is the amount the firm reports that it has repatriated or plans to repatriate divided by world-wide assets. Size is the log of the market value of equity. Market value of equity equals price (data14) times common shares outstanding (data61). $\triangle C a p E x$ is the change in the ratio of capital expenditures (data90) to world-wide assets (data44) from the beginning of quarter t- 4 to the beginning of quarter t. $\triangle R O A$ is the change in the ratio of net income (data69*4) to world-wide assets (data44) from quarter t-1 to quarter t. ROA is the ratio of net income (data69*4) to world-wide assets (data44). Debt is the ratio of long-term debt (data51) plus debt in current liabilities (data45) to world-wide assets (data44). DivYld is dividends per share (data16) scaled by price (data14).

$\Delta$ Cash is the change in the ratio of cash and cash equivalents (data36) to world-wide assets (data44) from the beginning of quarter t-4 to the beginning of quarter t. $\Delta$ Penalty equals the change in the dividend tax penalty from quarter $t-4$ to quarter $t$ and the dividend tax penalty equals the dividend tax rate minus the capital gain tax rate divided by one minus the capital gain tax rate.

\begin{tabular}{|c|c|c|c|c|c|c|c|c|c|}
\hline \multicolumn{10}{|c|}{ Panel A: Compustat Measures } \\
\hline \multirow[t]{2}{*}{ Variable } & \multirow[b]{2}{*}{ Pred. } & \multicolumn{2}{|c|}{ (1) $\Delta$ Payout } & \multicolumn{2}{|c|}{ (2) $\Delta$ Dividends } & \multicolumn{2}{|c|}{ (3) $\Delta$ ShrRep } & \multicolumn{2}{|c|}{ (4) $\Delta$ ShrRep } \\
\hline & & Coefficient & t-statistic & Coefficient & t-statistic & Coefficient & t-statistic & Coefficient & t-statistic \\
\hline Intercept & ? & 0.00084 & 1.96 & 0.00026 & 2.55 & 0.00020 & 0.43 & 0.00025 & 0.56 \\
\hline PostAct & $?$ & 0.00148 & 7.96 & 0.00041 & 6.60 & 0.00111 & 6.19 & 0.00126 & 7.16 \\
\hline Repatriate & $?$ & -0.00027 & -1.71 & -0.00002 & -0.71 & -0.00026 & -1.69 & & \\
\hline PostAct*Repatriate & + & 0.00281 & 4.44 & 0.00004 & 0.27 & 0.00277 & 4.28 & & \\
\hline MaxRep & $?$ & & & & & & & -0.00001 & -0.09 \\
\hline PostAct*MaxRep & + & & & & & & & 0.01937 & 3.47 \\
\hline Size $_{\mathrm{t}-1}$ & + & 0.00016 & 6.84 & -0.00001 & -2.03 & 0.00020 & 8.67 & 0.00019 & 8.36 \\
\hline$\Delta \mathrm{CapEx}_{\mathrm{t}-1}$ & - & -0.00063 & -0.38 & -0.00008 & -0.12 & -0.00086 & -0.51 & -0.00081 & -0.48 \\
\hline$\Delta \mathrm{ROA}_{\mathrm{t}}$ & $?$ & -0.00111 & -4.49 & -0.00043 & -5.58 & -0.00042 & -1.71 & -0.00041 & -1.66 \\
\hline $\mathrm{ROA}_{\mathrm{t}}$ & + & 0.00333 & 12.34 & 0.00086 & 9.80 & 0.00203 & 8.02 & 0.00201 & 7.93 \\
\hline Debt $_{t-1}$ & - & -0.00404 & -16.96 & -0.00096 & -11.36 & -0.00308 & -13.71 & -0.00309 & -13.78 \\
\hline DivYld $_{t-1}$ & $? /-$ & -0.02956 & -2.81 & 0.00017 & 0.03 & -0.04889 & -6.07 & -0.04918 & -6.09 \\
\hline$\Delta \operatorname{Cash}_{\mathrm{t}-1}$ & + & 0.00530 & 10.43 & 0.00090 & 5.26 & 0.00508 & 10.22 & 0.00509 & 10.23 \\
\hline$\Delta$ Penalty $_{\mathrm{t}}$ & $+/-$ & 0.00140 & 2.63 & -0.00201 & -12.27 & 0.00339 & 6.50 & 0.00334 & 6.38 \\
\hline$\Delta$ Payout $_{\mathrm{t}-4}$ & - & -0.44744 & -52.37 & & & & & & \\
\hline$\Delta$ Dividends $_{\mathrm{t}-4}$ & - & & & -0.32621 & -15.77 & & & & \\
\hline$\Delta$ ShrRept-4 $_{\mathrm{t}}$ & - & & & & & -0.45828 & -51.50 & -0.45819 & -51.41 \\
\hline $\mathrm{N}$ & & 114,973 & & 114,973 & & 115,564 & & 115,020 & \\
\hline Adj. R Square & & 0.1844 & & 0.0693 & & 0.1986 & & 0.1984 & \\
\hline
\end{tabular}


TABLE 8 Continued

\begin{tabular}{|c|c|c|c|c|c|c|c|c|c|}
\hline \multicolumn{10}{|c|}{ 1 ABLE 8 Contmued } \\
\hline \multicolumn{10}{|c|}{ Panel B: CRSP Measures } \\
\hline \multirow[t]{2}{*}{ Variable } & \multirow[b]{2}{*}{ Pred. } & \multicolumn{2}{|c|}{ (1) $\Delta$ Payout } & \multicolumn{2}{|c|}{ (2) $\Delta$ Dividends } & \multicolumn{2}{|c|}{ (3) $\Delta$ ShrRep } & \multicolumn{2}{|c|}{ (4) $\Delta$ ShrRep } \\
\hline & & Coefficient & t-statistic & Coefficient & t-statistic & Coefficient & t-statistic & Coefficient & t-statistic \\
\hline Intercept & ? & 0.00076 & 1.55 & 0.00019 & 2.22 & 0.00031 & 0.73 & 0.00041 & 0.96 \\
\hline PostAct & ? & 0.00099 & 4.58 & 0.00028 & 5.89 & 0.00073 & 3.99 & 0.00088 & 4.94 \\
\hline Repatriate & ? & -0.00047 & -2.81 & -0.00006 & -2.16 & -0.00037 & -2.49 & & \\
\hline $\begin{array}{l}\text { PostAct* } \\
\text { Repatriate }\end{array}$ & + & 0.00267 & 3.93 & 0.00017 & 1.21 & 0.00254 & 4.23 & & \\
\hline MaxRep & ? & & & & & & & -0.00008 & -0.81 \\
\hline PostAct*MaxRep & + & & & & & & & 0.01671 & 3.09 \\
\hline Size $_{t-1}$ & + & 0.00010 & 3.92 & 0.00000 & -0.23 & 0.00013 & 5.61 & 0.00011 & 5.05 \\
\hline$\Delta \mathrm{CapEx}_{\mathrm{t}-1}$ & - & 0.00296 & 1.48 & -0.00003 & -0.06 & 0.00287 & 1.63 & 0.00284 & 1.61 \\
\hline$\Delta \mathrm{ROA}_{\mathrm{t}}$ & ? & -0.00118 & -3.91 & -0.00031 & -5.35 & -0.00054 & -2.17 & -0.00052 & -2.11 \\
\hline $\mathrm{ROA}_{\mathrm{t}}$ & + & 0.00313 & 9.29 & 0.00071 & 9.61 & 0.00160 & 5.95 & 0.00159 & 5.87 \\
\hline Debt $_{t-1}$ & - & -0.00360 & -13.25 & -0.00084 & -11.00 & -0.00212 & -9.84 & -0.00215 & -9.98 \\
\hline $\operatorname{DivYld}_{\mathrm{t}-1}$ & ?/- & -0.00589 & -0.53 & -0.00105 & -0.23 & -0.03582 & -4.90 & -0.03618 & -4.94 \\
\hline$\Delta \operatorname{Cash}_{\mathrm{t}-1}$ & + & 0.00327 & 5.68 & 0.00063 & 4.62 & 0.00203 & 4.22 & 0.00202 & 4.20 \\
\hline$\Delta$ Penalty ${ }_{\mathrm{t}}$ & $+/-$ & 0.00025 & 0.40 & -0.00183 & -12.55 & 0.00302 & 5.69 & 0.00294 & 5.53 \\
\hline$\Delta$ Payout $_{\mathrm{t}-4}$ & - & -0.47069 & -51.73 & & & & & & \\
\hline$\Delta$ Dividends $_{\mathrm{t}-4}$ & - & & & -0.32009 & -15.71 & & & & \\
\hline$\Delta$ ShrRep $_{\mathrm{t}-4}$ & - & & & & & -0.47820 & -56.89 & -0.47840 & -56.76 \\
\hline $\mathrm{N}$ & & 115,564 & & 115,564 & & 115,569 & & 115,569 & \\
\hline Adj. R Square & & 0.2031 & & 0.0714 & & 0.2150 & & 0.2149 & \\
\hline
\end{tabular}




\section{TABLE 9}

\section{Results of Two Stage Model to Correct for Self-selection Bias}

The dependent variable in Panel A is Repatriate, a dummy variable equal to one for firms that repatriate under the Act. The coefficients in Panel A are estimated using a Probit regression. FPTI is the mean ratio of foreign pre-tax income to world-wide assets from 2002 through 2004. ROA is the mean ratio of net income to world-wide assets from 2002 through 2004 . Assets is the $\log$ of world-wide assets at the end of 2004. All other variables in Panel A are defined in Table 3.The dependent variable in Panel B is the annual change from 2004 to 2005 in total repurchases, $\Delta S h r R e p$, measured as the change in treasury stock scaled by world-wide assets. If there is a net decrease in treasury stock, then repurchases equals zero. For those firms that do not use the treasury stock method, we estimate share repurchases as repurchases of common and preferred stock from the statement of cash flows less decreases in preferred stock. The coefficients in Panel B are estimated using a two-step procedure to control for self-selection in the decision to repatriate and includes the inverse Mills ratio from the probit estimation. Standard errors are corrected for correlation between the equations (Maddala 1983). Size is the log of the market value of equity at the end of 2004. $\triangle C a p E x$ is the change in the ratio of capital expenditures to world-wide assets from the beginning of 2004 to the beginning of 2005. $\triangle R O A$ is the change in the ratio of net income to world-wide assets from 2004 to 2005. Debt is the ratio of long-term debt plus debt in current liabilities to world-wide assets at the end of 2004. DivYld is 2004 dividends per share scaled by price. $\Delta$ Cash is the change in the ratio of cash and cash equivalents to world-wide assets from the beginning of 2004 to the beginning of 2005. The sample includes 2,690 firms with necessary Compustat data available for the period 2001 to 2005, excluding firms with negative book values, firms incorporated outside the U.S, insurance companies, financial services firms, and firms with missing foreign activity in each of the previous three years.

\begin{tabular}{|c|c|c|c|}
\hline \multicolumn{4}{|c|}{ Panel A: Probit Model of Repatriation } \\
\hline Variable & Predicted Sign & Coefficient & z-statistic \\
\hline Intercept & & -2.15110 & -25.33 \\
\hline$\Delta$ FPTI & - & -0.29828 & -2.31 \\
\hline$\Delta \mathrm{ROA}$ & - & -2.33869 & -2.21 \\
\hline$\Delta \mathrm{MB}$ & - & -0.02027 & -0.65 \\
\hline$\Delta \mathrm{RD}$ & - & 2.21524 & 0.51 \\
\hline$\Delta$ CapEx & - & -1.29853 & -0.48 \\
\hline FCF & + & 2.54592 & 4.68 \\
\hline RateDum & + & 0.88904 & 7.98 \\
\hline USTR & + & 0.83603 & 2.81 \\
\hline \%FAssets & + & 0.56244 & 4.53 \\
\hline FPTI & + & 10.74749 & 7.02 \\
\hline ROA & + & 0.84656 & 2.21 \\
\hline Assets & + & 0.00001 & 4.89 \\
\hline $\mathrm{N}$ & & 2,696 & \\
\hline \multicolumn{4}{|c|}{ Panel B: Repurchases Model } \\
\hline Variable & Predicted Sign & Coefficient & z-statistic \\
\hline Intercept & & -0.00911 & -1.37 \\
\hline Repatriate & + & 0.00978 & 2.15 \\
\hline Size & + & 0.00288 & 6.67 \\
\hline$\Delta$ CapEx & - & -0.00200 & -0.09 \\
\hline$\triangle \mathrm{ROA}$ & + & 0.00710 & 1.94 \\
\hline Debt & - & -0.01927 & -4.52 \\
\hline DivYld & ? & -0.14119 & -2.72 \\
\hline$\Delta$ Cash & + & 0.00761 & 3.04 \\
\hline$\Delta$ ShrRep $_{\mathrm{t}-1}$ & - & -0.43807 & -20.56 \\
\hline Inv. Mills Ratio & $?$ & -0.00911 & -1.37 \\
\hline $\mathrm{N}$ & & 2,696 & \\
\hline Wald Chi Square & & 541.15 & \\
\hline
\end{tabular}




\section{TABLE 10}

\section{Sensitivity Tests of Changes in Repurchases around the Act}

The dependent variable in Column (1) is abnormal repurchases calculated by estimating the following equation by firm for years t-5 through t-1: $\Delta S_{h} R e p_{t}=\gamma_{0}+\gamma_{1} R O A_{t}+$ $\gamma_{2} \operatorname{ShrRep}_{\mathrm{t}-1}+\eta_{t}$. Abnormal repurchases equals $\Delta S h r R e p_{\mathrm{t}}$ minus the predicted value from this equation. The dependent variable in Column (2) repeats the same process using ¿Payout in place of $\Delta$ ShrRep. The dependent variable in Columns (3) and (4) is $\Delta$ ShrRep. The sample includes firm-quarters from the first quarter of 1989 to the fourth quarter of 2005 with data available to calculate all regression variables, excluding firms incorporated outside the U.S., financial services firms, insurance companies, firms with no foreign activity in the previous three years, and firms with negative book values. In Column (3) we also eliminate firm-years for which $\Delta$ ShrRep equals zero. In Column (4) we also eliminate firms that do not report foreign segment sales. 4 ShrRep is the change from quarter $\mathrm{t}-4$ to quarter $\mathrm{t}$ in repurchases measured as the change in treasury stock (data226) scaled by world-wide assets (data44). If there is a net decrease in treasury stock, then repurchases equals zero. For those firms that do not use the treasury stock method, we estimate share repurchases as repurchases of common and preferred stock from the statement of cash flows (data 93) less decreases in preferred stock (change in data55 and data71). PostAct equals one for the four quarters of 2005, zero otherwise. Repatriate equals 1 if the firm states that it will repatriate under the Act. Size is the log of the market value of equity (price (data14) times common shares outstanding (data61)). $\triangle C a p E x$ is the change in the ratio of capital expenditures (data90) to world-wide assets (data44) from the beginning of quarter $\mathrm{t}-4$ to the beginning of quarter t. $\triangle R O A$ is the change in the ratio of net income (data69*4) to world-wide assets (data44) from quarter t-1 to quarter t. Debt is the ratio of long-term debt (data51) plus debt in current liabilities (data45) to world-wide assets (data44). DivYld is dividends per share (data16) scaled by price (data14). $\Delta$ Cash is the change in the ratio of cash and cash equivalents (data36) to world-wide assets (data44) from the beginning of quarter t-4 to the beginning of quarter $t$. $4 P e n a l t y$ equals the change in the dividend tax penalty from quarter $\mathrm{t}-4$ to quarter $\mathrm{t}$ and the dividend tax penalty equals the dividend tax rate minus the capital gain tax rate divided by one minus the capital gain tax rate.

\begin{tabular}{|c|c|c|c|c|c|c|c|c|c|}
\hline \multirow{3}{*}{ Variable } & \multirow[b]{3}{*}{ Pred. } & \multicolumn{4}{|c|}{ Abnormal Repurchases and Payout } & \multicolumn{4}{|c|}{ Reduced Samples } \\
\hline & & \multicolumn{2}{|c|}{ (1) Abnormal Repurchases } & \multicolumn{2}{|c|}{ (2) Abnormal Payout } & \multicolumn{2}{|c|}{ (3) Non-Zero Observations } & \multicolumn{2}{|c|}{ (4) Segment Sample } \\
\hline & & Coefficient & t-statistic & Coefficient & z-statistic & Coefficient & t-statistic & Coefficient & t-statistic \\
\hline Intercept & $?$ & 0.00059 & 1.60 & 0.00086 & 2.07 & 0.00318 & 2.68 & 0.00083 & 0.88 \\
\hline PostAct & $?$ & 0.00027 & 1.87 & 0.00031 & 1.81 & 0.00381 & 7.25 & 0.00145 & 5.28 \\
\hline Repatriate & $?$ & 0.00058 & 3.72 & 0.00102 & 5.92 & -0.00086 & -2.63 & -0.00016 & -0.89 \\
\hline $\begin{array}{l}\text { PostAct* } \\
\text { Repatriate }\end{array}$ & + & 0.00219 & 3.75 & 0.00175 & 2.77 & 0.00254 & 2.26 & 0.00229 & 3.26 \\
\hline Size $_{\mathrm{t}-1}$ & + & 0.00050 & 21.34 & 0.00077 & 29.76 & 0.00029 & 5.08 & 0.00024 & 6.90 \\
\hline$\Delta \mathrm{CapEx}_{\mathrm{t}-1}$ & - & 0.00070 & 0.44 & -0.00002 & -0.01 & -0.00373 & -0.62 & 0.00119 & 0.55 \\
\hline$\Delta \mathrm{ROA}_{\mathrm{t}}$ & $?$ & -0.00061 & -3.35 & -0.00067 & -3.14 & -0.00221 & -2.46 & -0.00029 & -1.23 \\
\hline $\mathrm{ROA}_{\mathrm{t}}$ & + & & & & & 0.00775 & 7.58 & 0.00076 & 1.48 \\
\hline Debt $_{t-1}$ & - & -0.00362 & -16.54 & -0.00666 & -24.23 & -0.00896 & -13.77 & -0.00487 & -11.89 \\
\hline $\operatorname{DivYld}_{\mathrm{t}-1}$ & $?$ & -0.04177 & -5.36 & 0.33617 & 26.77 & -0.14717 & -7.29 & -0.00768 & -2.84 \\
\hline$\Delta$ Cash $_{\mathrm{t}-1}$ & + & 0.00147 & 4.05 & 0.00135 & 3.29 & 0.01753 & 10.24 & 0.00614 & 8.21 \\
\hline$\Delta$ Penalty $_{\mathrm{t}}$ & + & 0.00304 & 5.65 & 0.00412 & 6.83 & 0.01032 & 6.98 & 0.00449 & 5.69 \\
\hline$\Delta$ ShrRep $_{\mathrm{t}-4}$ & - & & & & & -0.59108 & -58.14 & -0.45600 & -39.59 \\
\hline $\mathrm{N}$ & & 101,770 & & 101,468 & & 42,818 & & 64,334 & \\
\hline Adj. R Square & & 0.0201 & & 0.0588 & & 0.2663 & & 0.1994 & \\
\hline
\end{tabular}

